\title{
Implementation of the Use of Ethnomedicinal Plants for Curing Diseases in the Indian Himalayas and Its Role in Sustainability of Livelihoods and Socioeconomic Development
}

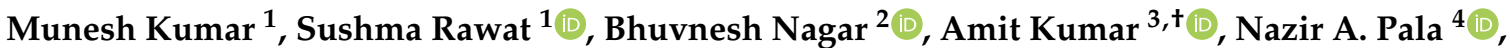 \\ Jahangeer A. Bhat ${ }^{5}\left(\mathbb{C}\right.$, Rainer W. Bussmann ${ }^{6}\left(\mathbb{D}\right.$, Marina Cabral-Pinto ${ }^{7, *(-)}$ and Ripu Kunwar ${ }^{8}(\mathbb{D}$ \\ 1 Department of Forestry and Natural Resources, HNB Garhwal University, \\ Srinagar-Garhwal 249161, Uttarakhand, India; muneshmzu@yahoo.com (M.K.); \\ rawatsushma26@gmail.com (S.R.) \\ 2 Department of Forest Products and Utilization, College of Horticulture and Forestry, \\ Jhalawar 326023, Rajasthan, India; bhuwi@hotmail.com \\ 3 School of Hydrology and Water Resources, Nanjing University of Information Science and Technology, \\ Nanjing 210044, China; amit.ag109@gmail.com or amitkdah@nuist.edu.cn \\ 4 Faculty of Forestry, Sher-e-Kashmir University of Agriculture Sciences and Technology of Kashmir, \\ Jammu and Kashmir 190025, India; nazirpaul@gmail.com \\ 5 Department of Forest Products and Utilization, College of Horticulture and Forestry, Rani Lakshmi Bai \\ Central Agricultural University, Jhansi 284003, Uttar Pradesh, India; jahan191@gmail.com \\ Citation: Kumar, M.; Rawat, S.; \\ Nagar, B.; Kumar, A.; Pala, N.A.; Bhat, \\ J.A.; Bussmann, R.W.; Cabral-Pinto, \\ 6 Department of Ethnobotany, Institute of Botany, Ilia State University, Tbilisi 0105, Georgia; \\ rainer.bussmann@iliauni.edu.ge \\ 7 Department of Geosciences, University of Aveiro, Campus de Santiago, 3810-193 Aveiro, Portugal \\ 8 Ethnobotanical Society of Nepal, Kathmandu 44600, Nepal; ripukunwar@gmail.com \\ * Correspondence: marinacp@ua.pt \\ + Co-Corresponding author.
}

M.; Kunwar, R. Implementation of the Use of Ethnomedicinal Plants for Curing Diseases in the Indian Himalayas and Its Role in Sustainability of Livelihoods and Socioeconomic Development. Int. J. Environ. Res. Public Health 2021, 18 , 1509. https://doi.org/10.3390/ ijerph18041509

Academic Editor: William A. Toscano Received: 24 November 2020

Accepted: 23 January 2021

Published: 5 February 2021

Publisher's Note: MDPI stays neutral with regard to jurisdictional claims in published maps and institutional affiliations.

Copyright: (c) 2021 by the authors. Licensee MDPI, Basel, Switzerland. This article is an open access article distributed under the terms and conditions of the Creative Commons Attribution (CC BY) license (https:/ creativecommons.org/licenses/by/ $4.0 /)$
Abstract: In recent times, the use of traditional herbal medicines in healthcare has declined, particularly amongst the rural population. This implies a risk of losing vital information from previous generations regarding plants and their use in traditional medicine. The objective of this study is to catalog the ways employed by inhabitants of the Garhwal Himalayas as part of their traditional approaches to healthcare. Information was gathered through snowball sampling using a questionnaire combined with informal interviews. This was supplemented by discussions with peers and practitioners prominent in this healing technique. The homogeneity within ethnomedicinal knowledge of these rural residents was tested using the informant consensus factor (Fic). The calculation of the fidelity value (FL) and the cultural importance index (CI) were made regarding the population's dependency on plants. A total of 88 plant species from 44 families and 80 genera were identified as medicines for various complaints. Leaves were the most frequently used plant part followed by fruits, seeds, roots, bark, and flowers/buds. The largest number of taxa (15 species) were used for treatment of skin ailments (with Fic score of 0.85 ) followed by wounds, coughs, and digestive problems. There was a significant relationship observed between the medicinal plants used and distance (time of access) and family income. The present study will provide baseline information to be established for future research. The available information could help to discover new drugs for the pharmaceutical industry. Thus, the study revealed that the plants that have high scores of FL and $\mathrm{CI}$ can be used to discover new drug extraction in the future for further studies.

Keywords: socio-economic factors; Himalayas; healthcare; rural inhabitants; medicinal plant; Forestry

\section{Introduction}

Humans have always used plants to enhance physical and spiritual wellbeing [1], and medicinal plants have continued to gain prominence, even in the modern era [2]. In the modern era, about 40,000-50,000 plant species are being used for traditional healthcare, 
and to discover drugs all around the globe [3]. According to the World Health Organization (WHO), 65-80\% of the world's population, particularly in developing countries, depend on plants for healing, and this is well accepted in traditional culture [4], often due to poverty, and lack of access to modern medicine [5]. Traditionally used medicinal plants have a long history of use as they are often considered safe and non-toxic to human beings [6]. Most people residing in rural areas depend on subsistence agriculture for their survival and have a great cultural knowledge of curing diseases by the utilization of forest resources [7]. However, lack of documentation of traditional practice by the healers leads to the unclear effect of herbal medicine among the present generation [8]. These traditional resources sometimes play an important role in the subsistence of local inhabitants and even income generation. Wild collection practices secure valuable income for many rural households and provide incentives for conservation and sustainable use [9]. The current market of herbal drugs is estimated at 40 billion and is expected to increase by $16 \%$ in the next 3-4 years. However, production of many herbs is less than market demand, which incentivizes adulteration in the Ayurvedic drugs [10].

Ethnobotanical knowledge arises from a complex interaction between human beings and their surrounding environment, which depends on various factors including local classification systems [11], communication through language [12], human cognition and cultural history [13], beliefs and religion [14], social networks and access to information [15]. Ethnomedicinal research is the study of unique knowledge about plant wealth and search of new resources for the preparation of herbal medicines, edible plants for consumption, and other aspects of plants [16]. In India, 20\% of plant species are reported for medicinal values [17]. Uttarakhand, a Himalayan state, well known for its biotic wealth and variety of cultural heritage, covers about $12.18 \%$ of the total Indian Himalaya, and harbors more than $40 \%$ of its diverse forest types, comprising the highest cover of natural forest and alpine pastures [18]. The diverse ethnic communities (i.e., Garhwali, Jaunsari, Bhotia, Tharu, etc.) living in the state are dependent on forests for their primary healthcare and their livelihoods [7].

Herbal practice still plays a significant role in managing and curing various health problems, particularly in the remote and rural areas of India [19]. The knowledge of medicinal plant conservation and its use has developed a link between promoting environmental conservation and indigenous knowledge [20]. In the present scenario, the practice of herbal medicine has, however, been declining even in the places where it was once developed and nurtured by oral tradition down generations. The decline of herbal medicine use is especially rooted in the change of people's attitudes towards allopathic medicine, and the wide availability of it even in small towns, although people are well aware of its possible side effects. This situation may lead to the loss of traditional and valuable information about the plants used in healthcare management in the future [21]. Allopathic medicine is, however, still out of reach for the majority of villagers. Thus, our target groups in this study were especially local poor people who have fewer facilities and live away from the cities. The documentation of traditional healthcare practices can help planners and policymakers in better management and sustainable use of such local resources.

Ethnobotany is valuable for the development of healthcare and conservation programs in different parts of the world. The documentation of ethnobotanical studies helps to preserve knowledge before traditional folklores are lost forever [22]. The World Health Organization estimates that $80 \%$ of the world's population relies on traditional systems of medicine. These medicinal plants form an important part of the world's economy because many modern medicines are derived from these plants. Indian indigenous systems of medicine are mainly based on the use of plants. Every year, the medicinal plant-related trade grows rapidly, and while India's share in the global market is not very impressive (only $0.5-1 \%$ ), demand for these products is increasing at an alarming rate [23]. Rural communities depend largely on herbal resources for curing diseases. This culture continues today in the form of folk medicine in different parts of the world and led to the development of traditional systems of medicine. Systematic and scientific investigations of traditional 
medicinal plants have also provided many valuable drugs in Western medicine [24]. Thus, considering the value of medicinal plant documentation for further conservation is highly important before they vanish from nature. The valuable plant information from this region needs to be systematically collected and documented for generations to come, apart from conserving these precious plant resources of high economic utility. The present study was designed to (i) document the use of ethnomedicinal plants in the villages of the Gharwal Himalayas (ii) to find consensus on information on the use of each plant in the study area and (iii) to understand the socioeconomic status of the people vs. the potential use of traditional medicine.

\section{Materials and Methods}

\subsection{Study Area}

The present study was conducted in Pauri Garhwal and Rudraprayag districts of Uttarakhand, India (Figure 1). These ranges of districts extend from $29^{\circ} 30^{\prime}-30^{\circ} 50^{\prime} \mathrm{N}$ latitude and $78^{\circ} 10^{\prime}-79^{\circ} 20^{\prime} \mathrm{E}$ longitude. However, within these two districts, the different altitudinal ranges (1000-3000 m above sea level; masl) have been selected (Figure 1), and study surveyed villages were between 700 to 1800 masl. The rainfall pattern in the region is largely governed by the monsoon rains from July to September, and account for $\sim 60-80 \%$ of the total annual rainfall [25]. The region is famous for its rich biodiversity, supporting different forest types, varying in species composition with elevation and latitude. The dominant tree species of the region reported is Pinus roxburghii (Chir pine).

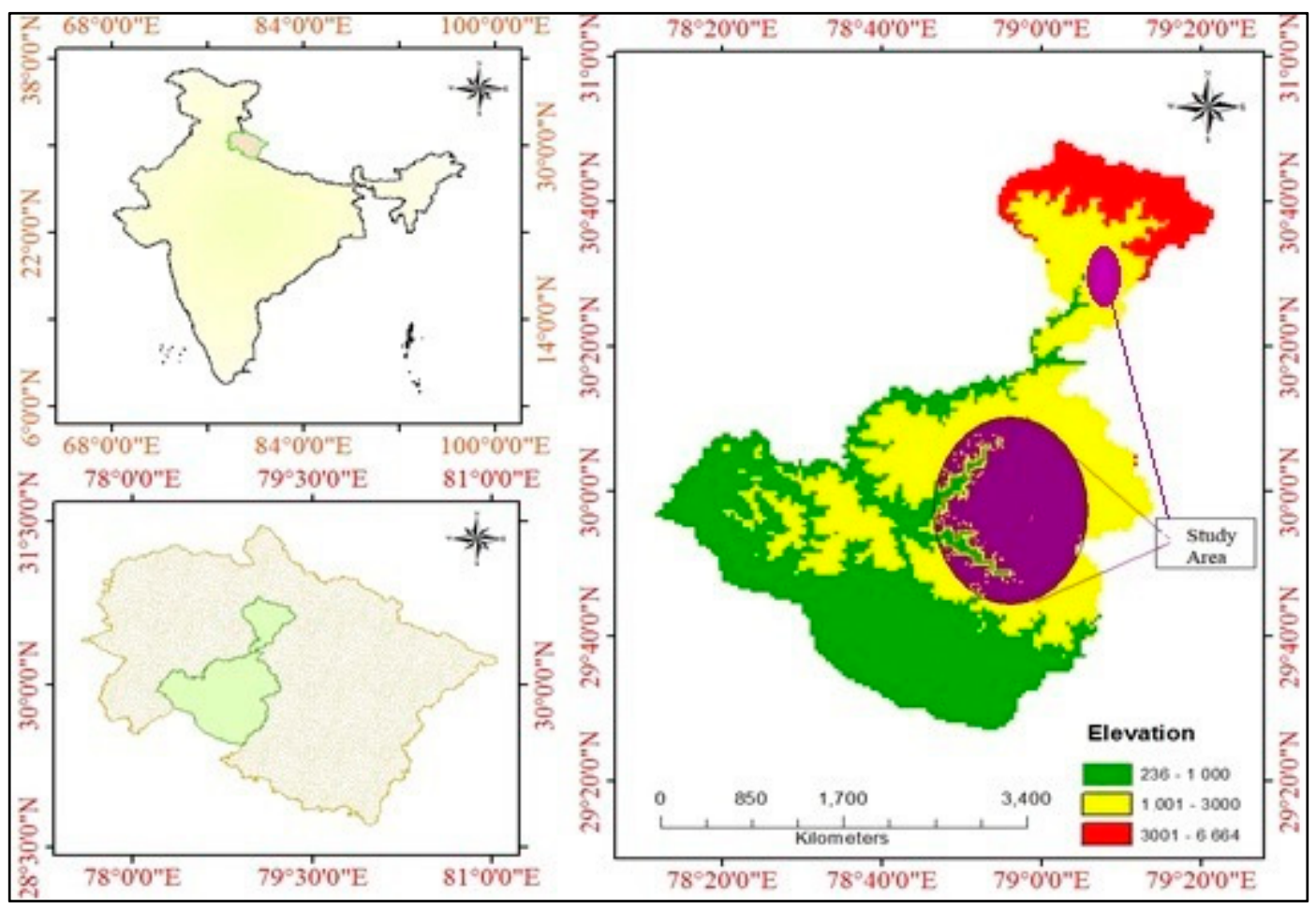

Figure 1. Location of the study area.

Agriculture is the primary profession of about $80 \%$ of the people in the western and central Himalayas [26] and about $70 \%$ of them have a land-holding size of less than 1 hectare [27]. Agricultural terraces are lined with numerous trees, wild bushes, grasses, and herbs that offer inhabitants fodder for livestock [28]. Inhabitants of the study area are dependent mainly on forests for diverse needs that are critical for the maintenance of their livelihoods and wellbeing. The livelihoods of the people are directly or indirectly derived from natural resources, traditional terrace-based rainfed agriculture, and animal husbandry 
practices as revealed by rural inhabitants. According to the 2011 census, population of both districts is 929,546 with an average literacy rate of $82.33 \%$ (Table 1) [29].

Table 1. Demographic status of the study area (Source: Census of India, 2011).

\begin{tabular}{|c|c|c|c|}
\hline \multirow{2}{*}{ Parameter } & \multirow{2}{*}{ Uttarakhand } & \multicolumn{2}{|c|}{ District } \\
\hline & & Pauri Garhwal & Rudraprayag \\
\hline \multicolumn{4}{|c|}{ Population } \\
\hline Male & $5,137,773$ & 326,829 & 114,589 \\
\hline Female & $4,948,519$ & 360,442 & 127,696 \\
\hline \multicolumn{4}{|c|}{ Literacy rate $(\%)$} \\
\hline Male & 87.4 & 92.71 & 93.90 \\
\hline Female & 70.01 & 72.60 & 70.35 \\
\hline \multicolumn{4}{|c|}{ Number of villages } \\
\hline Inhabited villages & 15,745 & 3142 & 653 \\
\hline Uninhabited villages & 1048 & 331 & 35 \\
\hline
\end{tabular}

\subsection{Sampling Techniques}

A test questionnaire was framed and used to test the suitability and flow of questions among 48 households with 21 and 27 in Pauri and Rudraprayag districts, respectively. After that, suitable and needful changes were made as per the requirement and incorporated in the final questionnaire (Appendix A). The final questionnaire was used to gather information through semi-structured interviews from 161 households (64 from Pauri and 97 from Rudraprayag). The snowball sampling technique was used for the selection of informants that had a sound traditional knowledge of medicinal plants used in the area. In the beginning, we approached the "Gram Pradhan" (a representative of the village; who keeps all information of the villages, including documentary proof) and older people of the village, who were reputed to know the medicinal plants used in the treatment of various health ailments. Once a traditional healer/plant collector was identified, snowball sampling was followed to locate and identify other respondents [30]. Since the younger generation had less awareness about traditional knowledge, respondents in the age group of 50-80 years were interviewed. A large number of respondents (75.3\%) were literate and friendly in disclosing the information about the traditional medicines that were passed on to them from their ancestors. The respondents of selected households were interviewed in their local language, i.e., Garhwali or Hindi. Before starting an interview, the inhabitants were advised about the purpose of the study and interview. Most of the information about the medicinal plants was recorded from the older people of the villages, including the importance of medicinal plants, plant parts used, name of the disease for which a particular plant was being used, etc. The published literature and consensus discussions with the inhabitants were also used for comparison. The used plants were collected and identified and confirmed from the traditional healers and participants. The Flora of Garhwal Himalayas was used to crosscheck the species local name and scientific nomenclature [31,32]. The specimens were then processed in the laboratory, verified by the curator, and submitted to Garhwal University Herbarium (GUH).

\subsection{Data Analysis}

The data collected during the fieldwork were analyzed for various parameters, i.e., informant's consensus factor (Fic), fidelity value (FL\%), and cultural importance index (CI). A consensus survey was conducted based on people's agreement on the number of plants used for a particular health ailment. To test the homogeneity of traditional medicinal knowledge about the plants, the informant's consensus factor (Fic) was used [33,34]. The Fic for each of the recorded plant species was calculated using the following formula:

$$
F_{i c}=\frac{N_{u r}-N_{t}}{N_{u r}-1}
$$


where $\mathrm{N}_{\mathrm{ur}}$ is the number of use reports for a particular health problem and $\mathrm{N}_{t}$ is the number of species used for a particular health problem by all the informants. The resulting factor ranges from 0 to 1 , where high value reveals high rate of informant consensus. The fidelity level [35] is the percentage of informants claiming the use of a certain plant species for the same major purpose, and was calculated as:

$$
\text { Fidelity value }(\mathrm{FL}, \%)=\frac{\mathrm{I}_{\mathrm{p}}}{\mathrm{I}_{\mathrm{u}}} \times 100
$$

where $I_{p}$ is the number of informants indicating independent use of a species for the same major ailment and $\mathrm{I}_{\mathrm{u}}$ is the total number of informants mentioning the use of plants for any major ailment. Cultural Importance Index (CI) was calculated by dividing the number of use report (UR) in use-category by the number of informants [33] to assess the importance of each species using the following formula:

$$
\mathrm{CI}_{\mathrm{s}}=\sum_{\mathrm{u}=\mathrm{u}_{1}}^{\mathrm{u}_{\mathrm{NC}}} \sum_{\mathrm{i}=\mathrm{i}_{1}}^{\mathrm{i}_{\mathrm{N}}} \frac{\mathrm{UR}_{\mathrm{ui}}}{\mathrm{N}}
$$

where UR is the number of useful reports in various health problems (NC) and (N) is the total number of informants.

One-way ANOVA and binary logistic regression analysis were used to estimate the relationship between various household factors and the use of medicinal plants. The description of various explanatory variables has been provided in Table 2, where resources for each category and indicator selected for the household environment were aggregated through relevant indices after normalizing each sub-category, respectively, through the standard protocol of min-max approach. The statistical test of significance of variables is given in Table 3.

\begin{tabular}{|c|c|}
\hline Variable Name & Description \\
\hline GEN & Gender of respondent ( 1 if male, 0 for female) \\
\hline AGE & Age of respondent (in years) \\
\hline EDU & $\begin{array}{c}\text { Education level of respondent ( } 0 \text { for illiterate, } 1 \text { for literate, } 2 \text { for } \\
\text { primary, } 3 \text { for high school, } 4 \text { for intermediate, } 5 \text { for bachelor and } \\
\text { above }\end{array}$ \\
\hline PROF & $\begin{array}{c}\text { Profession (1 for others, } 2 \text { for wage labor, } 3 \text { for business, } 4 \text { for } \\
\text { agriculture, } 5 \text { for service) }\end{array}$ \\
\hline HEAL & Healer (1 for yes, 0 for no) \\
\hline DISTFOR & Distance from forest (in km) \\
\hline DISTHOSP & Distance from hospital (in km) \\
\hline INCOME & $\begin{array}{l}\text { Monthly income ( } 1 \text { for Below, } 2 \text { for Rs. } 3000-6000,3 \text { for Rs. } \\
6000-12,000,4 \text { for Rs. } 12,000-24,000)\end{array}$ \\
\hline
\end{tabular}

Table 2. Description of variables used.

Table 3. ANOVA test for significance of variables.

\begin{tabular}{ccccc}
\hline Variables & Average & Std Dev & $\begin{array}{c}\text { Standard Error } \\
\text { (SE) }\end{array}$ & F Value (sig.) \\
\hline GEN & - & - & - & Ns \\
AGE & 62.211 & 8.6627 & 0.6827 & Ns \\
EDU & - & - & - & Ns \\
PROF & - & - & - & Ns \\
HEAL & - & - & - & $4.766(0.001)$ \\
DISTFOR & 1.646 & 0.9281 & 0.0731 & $3.600(0.000)$ \\
DISTHOSP & 8.646 & 6.7446 & 0.5315 & $8.614(0.000)$ \\
INCOME & - & - & - &
\end{tabular}

Ns: non-significant. 


\section{Results}

The existing traditions of managing different diseases by the inhabitants of Pauri and Rudraprayag district were recorded and the complete details are presented in Appendix B. A total of 88 medicinal plants were recorded from 44 families and 80 genera. The plant parts were used including leaves, roots, fruits, seeds, bark, flowers, and underground parts. In the present study, the maximum number of plant species ( 15 species) were used for skin treatment followed by the wound, cough (10 each); digestive problems (09); diabetes (08); respiratory problems (07); stomach problems (06); blood pressure, cattle diseases, dysentery, fever, ulcer (05); cut wounds, diarrhea, eye problems (04); piles, hair treatment, skin burn (03 each); rheumatic pain, cholesterol problems, liver problems, appetite improvement, earache, cold, bone problems, astringent, anemia, urinary issues (02 each); antioxidant, backache, cancer and tuberculosis, throat infections, dengue, heel crack, insecticide and nematicide, kidney stones, paralysis, pyorrhea, scorpion bites and snake bites, toothache (01 each) (Figure 2).

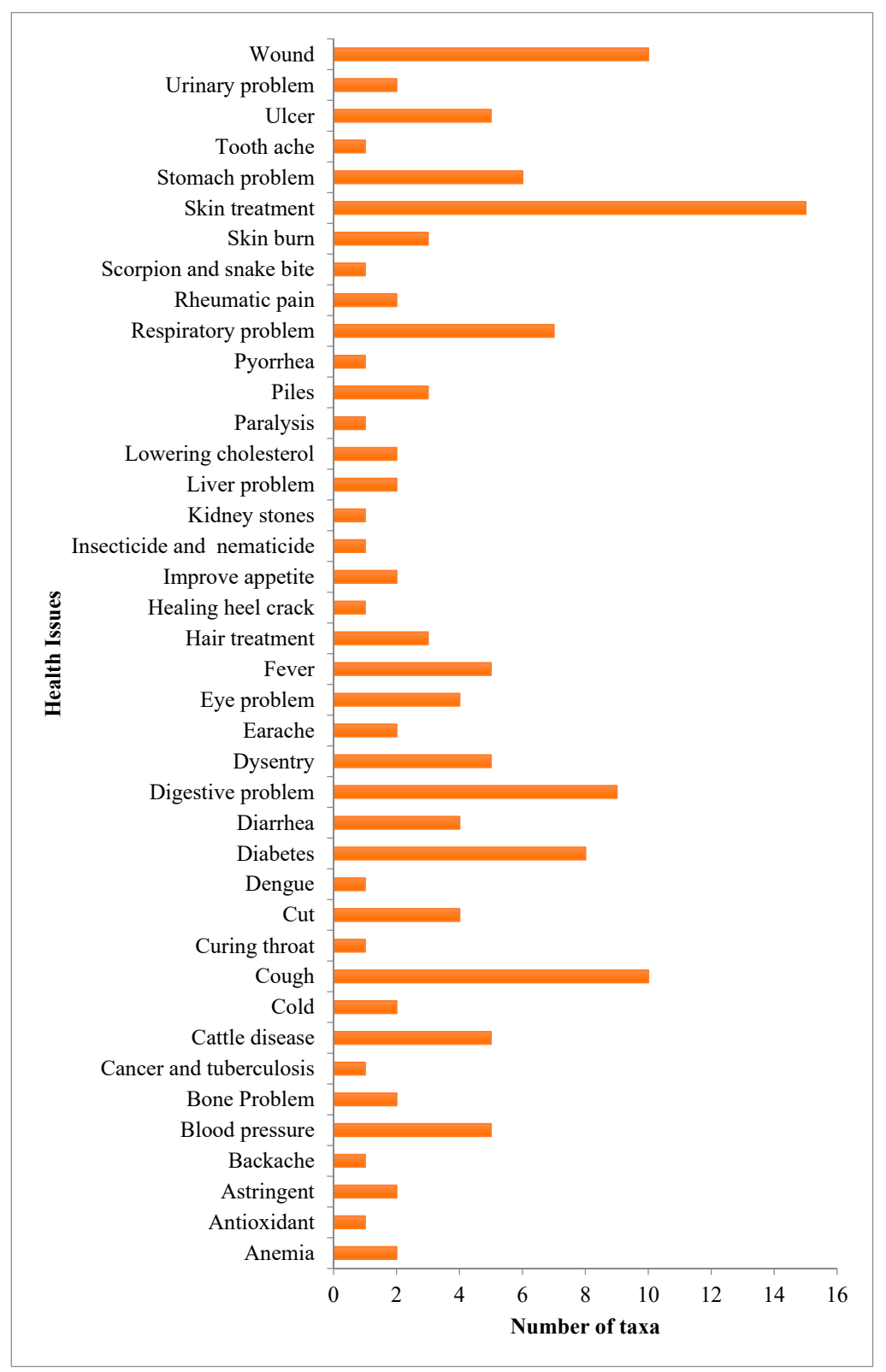

Figure 2. Number of plant species (taxa) used to treat different health conditions. 
Among the different plant parts used to cure various diseases, leaves contributed the most $(30.7 \%)$, followed by fruits $(27.3 \%)$, seeds $(17 \%)$, roots $(12.5 \%)$, bark $(10.2 \%)$, flowers $(8 \%)$, whole plants (6.8\%); tuber/rhizome/bulb, twig, latex (4.5\% each); gum and stem $(2.3 \%$ each) and resin, pollen dust ( $1.1 \%$ each) (Figure 3$)$. Practice of using medicinal plant resources in healthcare management by rural households' as a part of their cultural tradition is passed on to them from generations. This observation during the study reveals that local people are dependent on these plants for their daily needs, especially medicines and nutrition.

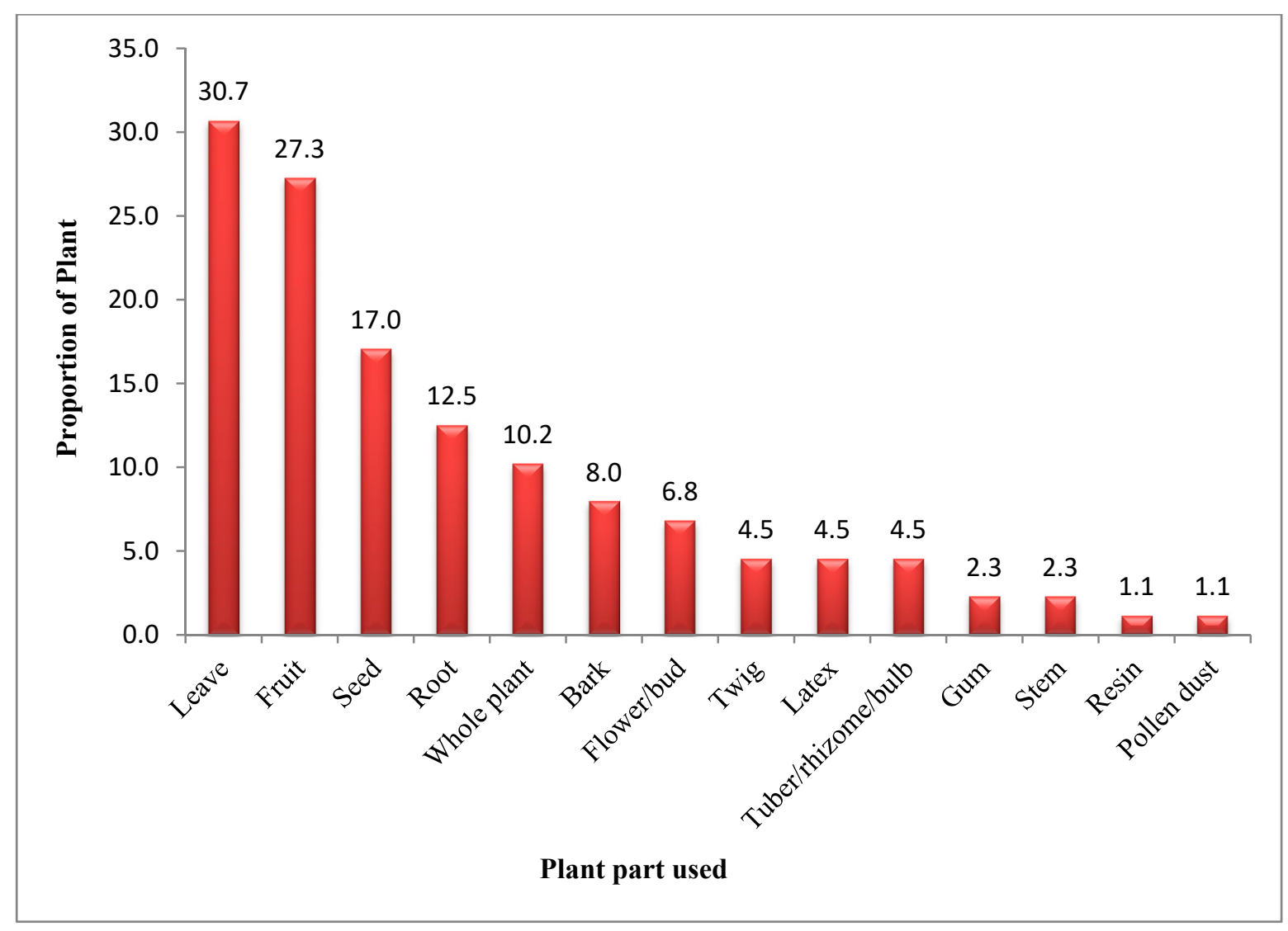

Figure 3. Proportion of different plant parts used in curing health problems.

\subsection{Health Problem and Uses}

Medicinal plants used for different ailments were classified into 40 groups and Fic values for each category are mentioned in Table 4 . The results of the Fic showed that the antioxidant; back-ache; cancer and tuberculosis (pollen dust and resin of Pinus roxburghii Sarg. with water is useful for tuberculosis); dengue, healing heal crack; insecticide and nematicide; kidney stones; paralysis; pyorrhea; scorpion and snake bites; toothache and throat infections; category had the greatest agreement with a Fic of (1.00), followed by cold, appetite improvements and cholesterol level reduction (0.98); hair treatments (0.97); urinary infections and bone problems (0.96); earache and eye problems (0.95); astringent and cuts (0.94). The least agreement between the informants was recorded in the piles and ulcer with Fic value of (0.50). Skin problems were cured with the highest number of taxa (15 spp.) with Fic value of 0.85 (Table 3). The awareness about the species used in skin-related problems was observed as high in the study area. 
Table 4. Informant consensus of ethnomedicinal plants.

\begin{tabular}{|c|c|c|c|}
\hline Health Problems $\left(F_{i c}\right)$ & $\begin{array}{c}\text { Number of } \\
\text { Taxa Used }\left(N_{t}\right)\end{array}$ & $\begin{array}{l}\text { Number of Use } \\
\text { Reports }\left(N_{u r}\right)\end{array}$ & Species Fidelity Value (FL\%) \\
\hline Anemia (0.93) & 2 & 15 & Morus serrata $(100 \%)$, Luffa cylindrica $(46.2 \%)$ \\
\hline Antioxidant (1.00) & 1 & 12 & Prunus armeniaca $(42.9 \%)$ \\
\hline Astringent (0.94) & 2 & 18 & Prunus cerasoides (28.2\%), Ziziphus nummularia (77.8\%) \\
\hline Backache (1.00) & 1 & 21 & Prunus cerasoides $(53.8 \%)$ \\
\hline Blood pressure (0.92) & 5 & 54 & $\begin{array}{c}\text { Musa paradisiaca }(73.7 \%), \text { Bauhinia variegata }(54.5 \%), \text { Carica } \\
\text { papaya }(42.9 \%), \text { Cleome viscose }(100 \%), \text { Rhododendron arboreum } \\
(100 \%)\end{array}$ \\
\hline Bone Problem (0.96) & 2 & 28 & Sesamum orientale $(100 \%)$, Bombax ceiba $(100 \%)$ \\
\hline $\begin{array}{l}\text { Cancer and tuberculosis } \\
(1.00)\end{array}$ & 1 & 2 & Pinus roxburghii (5.1\%) \\
\hline Cattle disease (0.90) & 5 & 43 & $\begin{array}{l}\text { Prunus persica }(100 \%) \text {, Quercus leucotrichophora }(100 \%), \text { Juglans } \\
\text { regia }(66.7 \%), \text { Reinwardita indica }(100 \%) \text {, Punica granatum } \\
(100 \%)\end{array}$ \\
\hline Cold (0.98) & 2 & 56 & Adhathoda vasica $(60 \%)$, Allium sativum $(100 \%)$ \\
\hline Cough (0.89) & 10 & 85 & $\begin{array}{c}\text { Datura stramonium }(60 \%) \text {, Myrica esculenta }(33.3 \%) \text {, Psidium } \\
\text { guajava }(100 \%) \text {, Ocimum sanctum }(85.7 \%) \text {, Cinnamom tamala } \\
(23.1 \%) \text {, Terminalia chebula }(65.2 \%) \text {, Terminalia belerica }(87.5 \%) \text {, } \\
\text { Adhathoda vasica }(20 \%) \text {, Mangifera indica }(48.3 \%) \text {, Semecarpus } \\
\text { anacardium }(33.3 \%)\end{array}$ \\
\hline Curing throat (1.00) & 1 & 15 & Cinnamomum tamala $(57.7 \%)$ \\
\hline Cut (0.94) & 4 & 52 & $\begin{array}{l}\text { Ficus roxburghii (37.1\%), Rhus parviflora }(35.0 \%) \text {, Anaphalis } \\
\text { adnata }(66.7 \%), \text { Eupatorium adenophorum }(64.9 \%)\end{array}$ \\
\hline Dengue (1.00) & 1 & 5 & Carrica papaya $(15.2 \%)$ \\
\hline Diabetes $(0.78)$ & 8 & 33 & $\begin{array}{c}\text { Aegle marmelos }(100 \%), \text { Ficus subincisa }(33.3 \%) \text {, Syzizium cumini } \\
(100 \%), \text { Musa paradisiaca }(15.8 \%), \text { Ocimum sanctum }(14.3 \%), \\
\text { Berberis asiatica }(36.4 \%), \text { Momordica charantia }(100 \%), \text { Asparagus } \\
\text { curillus }(100 \%)\end{array}$ \\
\hline Diarrhea $(0.73)$ & 4 & 12 & $\begin{array}{c}\text { Citrus limon }(100 \%) \text {, Ficus subincisa }(33.3 \%), \text { Ficus roxburghii } \\
(11.4 \%), \text { Semecarpus anacardium }(8.3 \%)\end{array}$ \\
\hline Digestive problem $(0.87)$ & 9 & 64 & $\begin{array}{c}\text { Prunus cerasoides }(17.9 \%) \text {, Myrica esculenta }(66.7 \%) \text {, Zea mays } \\
(100 \%) \text {, Ziziphus mauritiana (100\%), Oogenia oojenensis (100\%), } \\
\text { Tinospora cordifolia }(12.9 \%) \text {, Raphanus sativus }(52.4 \%) \text {, Lagenaria } \\
\text { siceraria }(31 \%) \text {, Mangifera indica }(51.7 \%)\end{array}$ \\
\hline Dysentery $(0.85)$ & 5 & 27 & $\begin{array}{c}\text { Ficus roxburghii }(25.7 \%), \text { Echinochloa crus-galli }(100 \%), \text { Butea } \\
\text { monosperma }(33.3 \%), \text { Woodfordia fruticosa }(100 \%), \text { Terminalia } \\
\text { belerica }(12.5 \%)\end{array}$ \\
\hline Earache (0.95) & 2 & 23 & Perilla frutescens (100\%), Artemisia wallichiana (36.4\%) \\
\hline Eye problem $(0.95)$ & 4 & 61 & $\begin{array}{c}\text { Hordeum vulgare }(100 \%), \text { Pyrus pashia }(100 \%), \text { Glycine max } \\
(100 \%), \text { Berberis asiatica }(63.6 \%)\end{array}$ \\
\hline Fever (0.91) & 5 & 47 & $\begin{array}{c}\text { Cynodon dactylon }(38.9 \%) \text {, Vitex negundo (19\%), Tinospora } \\
\text { cordifolia }(71 \%), \text { Cannabis sativa }(100 \%), \text { Carissa carandus } \\
(37.5 \%)\end{array}$ \\
\hline Hair treatment $(0.97)$ & 3 & 67 & $\begin{array}{c}\text { Grewia optiva }(100 \%), \text { Phyllanthus emblica }(69.7 \%), \text { Allium cepa } \\
(100 \%)\end{array}$ \\
\hline Healing heel crack (1.00) & 1 & 37 & Pinus roxburghii $(94.9 \%)$ \\
\hline Improve appetite (0.98) & 2 & 65 & Brassica campestris (100\%), Amaranthus spinosus (74.2\%) \\
\hline $\begin{array}{l}\text { Insecticide and nematicide } \\
\qquad(1.00)\end{array}$ & 1 & 3 & Ageratum coyzoides $(100 \%)$ \\
\hline Kidney stones (1.00) & 1 & 26 & Macrotyloma uniflorum $(100 \%)$ \\
\hline Liver problem (0.90) & 2 & 11 & Raphnus sativus (19\%), Luffa cylindrica (53.8\%) \\
\hline $\begin{array}{l}\text { Lowering cholesterol } \\
\qquad(0.98)\end{array}$ & 2 & 63 & Prunus armeniaca (57.1\%), Trigonella foenumgraecum (100\%) \\
\hline Paralysis (1.00) & 1 & 7 & Vitex negundo (33.3\%) \\
\hline
\end{tabular}


Table 4. Cont.

\begin{tabular}{|c|c|c|c|}
\hline Health Problems $\left(F_{i c}\right)$ & $\begin{array}{c}\text { Number of } \\
\text { Taxa Used }\left(N_{t}\right)\end{array}$ & $\begin{array}{l}\text { Number of Use } \\
\text { Reports }\left(N_{u r}\right)\end{array}$ & Species Fidelity Value ( $F L \%)$ \\
\hline Piles (0.50) & 3 & 5 & $\begin{array}{c}\text { Ficus subincisa }(33.3 \%), \text { Terminalia chebula }(4.3 \%), \text { Dioscorea } \\
\text { bulbifera }(66.7 \%)\end{array}$ \\
\hline Pyorrhea (1.00) & 1 & 11 & Bauhinia vahlii $(100 \%)$ \\
\hline Respiratory problem $(0.80)$ & 7 & 31 & $\begin{array}{c}\text { Murraya koenigii }(100 \%) \text {, Datura stramonium }(26.7 \%)(13.3 \%), \\
\text { Musa paradisiaca }(10.5 \%) \text {, Cinnamom tamala }(19.2 \%) \text {, Tinospora } \\
\text { cordifolia }(16.1 \%) \text {, Terminalia chebula }(26.1 \%)(4.3 \%), \text { Adhathoda } \\
\text { vasica }(13.3 \%)(6.7 \%)\end{array}$ \\
\hline Rheumatic pain $(0.80)$ & 2 & 6 & Abrus precatorius $(66.7 \%)$, Vitex negundo $(19 \%)$ \\
\hline $\begin{array}{l}\text { Scorpion and snake bite } \\
\qquad(1.00)\end{array}$ & 1 & 2 & Achyranthes aspera $(100 \%)$ \\
\hline Skin burn (0.94) & 3 & 37 & $\begin{array}{c}\text { Curcuma angustifolia }(100 \%), \text { Cynodon dactylon }(61.1 \%), \text { Sapium } \\
\text { insigne }(100 \%)\end{array}$ \\
\hline Skin treatment $(0.85)$ & 15 & 93 & $\begin{array}{c}\text { Rosa rubiginosa }(100 \%), \text { Rubus ellipticus }(60 \%), \text { Rumex hastatus } \\
(100 \%) \text {, Ziziphus nummularia }(22.2 \%), \text { Butea monosperma } \\
(66.7 \%), \text { Juglans regia }(33.3 \%), \text { Melia azederach }(100 \%) \text {, Raphanus } \\
\text { sativus (28.6\%), Bauhinia variegata }(45.5 \%) \text {, Shorea robusta } \\
(100 \%) \text {, Phyllanthus emblica }(30.3 \%) \text {, Semecarpus anacardium } \\
(58.3 \%) \text {, Coriandrum sativum }(100 \%) \text {, Calotropis procera }(100 \%) \text {, } \\
\text { Artemisia wallichiana }(27.3 \%)(20.5 \%)\end{array}$ \\
\hline Stomach problem $(0.91)$ & 6 & 59 & $\begin{array}{c}\text { Urtica dioica }(100 \%), \text { Oryza sativa }(100 \%) \text {, Mentha arvensis } \\
(100 \%), \text { Carica papaya }(57.1 \%), \text { Lagenaria siceraria }(31 \%), \\
\text { Amaranthus spinosus }(25.8 \%)\end{array}$ \\
\hline Tooth ache (1.00) & 1 & 23 & Zanthoxylum armatum $(100 \%)$ \\
\hline Ulcer (0.50) & 5 & 9 & $\begin{array}{c}\text { Rubus ellipticus }(40 \%) \text {, Oxalis corniculata }(30 \%) \text {, Abrus } \\
\text { precatorius }(33.3 \%) \text {, Dioscorea bulbifera }(33.3 \%), \text { Eupatorium } \\
\text { adenophorum }(5.4 \%)\end{array}$ \\
\hline Urinary problem $(0.96)$ & 2 & 27 & Lagenaria siceraria (37.9\%), Cucumis sativus (100\%) \\
\hline Wound (0.88) & 10 & 76 & $\begin{array}{c}\text { Ficus roxburghii }(25.7 \%) \text {, Ficus palmata }(100 \%) \text {, Oxalis } \\
\text { corniculata }(70 \%) \text {, Vitex negundo }(28.6 \%) \text {, Rhus parviflora }(65 \%) \text {, } \\
\text { Carissa carandus }(62.5 \%) \text {, Anaphalis adnata }(33.3 \%) \text {, Tagetus } \\
\text { minuta }(100 \%) \text {, Eupatorium adenophorum }(29.7 \%) \text {, Artemisia } \\
\text { wallichiana }(15.9 \%)\end{array}$ \\
\hline
\end{tabular}

The inhabitants of the study area are engaged in various activities and have to face many issues while collecting fuelwood and fodder; cooking food in traditional stoves; agricultural farming on hilly terrains; carrying portable water from distant places. These situations lead inhabitants to suffer from many skin-related problems, such as ringworm, skin disorders, skin allergy, fungal infection, skin dryness, skin infection, etc.

\subsection{Cultural Importance of Medicinal Plants}

The study results revealed that Trigonella foenum-graecum and Allium sativum with CI value 0.292 were the most used species in healthcare management with 47 use reports each The results further reported that the most important species used in treating skin-related problems were Artemisia wallichiana and Phyllanthus emblica with CI value 0.273 and 0.205 respectively indicating more use of these species by the inhabitants due to the availability of plant species and knowhow of their use in treating skin problems. The ANOVA analysis shows that distance of household from the hospital ( $\mathrm{F}=3.600 ; p<0.05)$ and monthly income of the family $(\mathrm{F}=8.614 ; p<0.05)$ are the main influencing factors favoring the use of medicinal plants for curing health problems, followed by a distance of household from forest $(\mathrm{F}=4.766 ; p<0.05)($ Table $2 \mathrm{~b})$.

\section{Discussion}

The results revealed that local traditional knowledge plays an essential role in primary healthcare and the practice of plant-based medicine is still prevalent in rural areas of the 
Garhwal region. Traditional herbal medicine is considered as the lifeline, the first choice, with fewer side effects, better patient tolerance, relatively economic, cultural recognition, and long history of use, in comparison to pharmaceutical medicine [36]. Local people show preferences for the use of traditional herbal remedies due to their belief in the effectiveness of folklore herbal remedies [19]. In this study, it was found that the use of ethnomedicinal plants was higher at increasing elevation due to a lack of alternative options and accessibility to markets. The use of indigenous medicine through local healers in remote areas is more demanding due to low prices because the cost of modern medicine is very high [37].

In an ethnomedicinal study of Kedarnath Wildlife Sanctuary, Malik et al. [19] reported that the most used plant part was roots (33\%), followed by leaves $(27 \%)$, bark $(20 \%)$, etc., which is different from our findings as the inhabitants were less aware of the medicinal use of root parts. Sharma et al. [25] also reported uses of different plant parts and the most commonly used plant part in the preparation of herbal ointments was leaves followed by seeds, roots, whole plant, stem, flower, and fruit. Ayyanar and Ignacimuthu [38] suggested that most of the studies confirmed the medicinal uses of leaves in the treatment of various health illnesses.

Informant's consensus factor is used to evaluate the reliability of the informant's information about plant use [39]. High Fic value indicates the use of some plants by many inhabitants in curing a particular health illness whereas low value means the use of different plants by many inhabitants in curing a particular health illness [40]. In the present study, informant's consensus survey indicated that twelve (12) plant species were most commonly used for individual diseases, and therefore the informant's consensus index factor was high (1.00). However, the lowest informant's consensus (0.50) was reported for piles and ulcers where only 3 and 5 plants were used for the curing diseases, respectively. The high degree of consensus of the informants indicated that current use and knowledge are still strong, so preservation of existing traditional knowledge needs to be done before much has been lost [39]. Therefore, local people showed high agreement on the usages of plants for specific ailments from the present study. The cultural importance of a plant depends on the versatility of plants with different uses to those with only one use [33]. This study also claimed the use of Artemisia spp. in treating various skin diseases [41].

Medicinal plants and their traditional formulations have always been a part of social life in rural communities, which have proved to be very helpful in tackling various healthrelated issues [42]. The dependency of the villagers on medicinal plants increased due to a lack of other healthcare facilities close to their households. Thus, informants of the study area reported that medicinal plants served as an important source for their healthcare, and the associated knowledge, which was traditionally transmitted and thus improved health conditions of human beings [43], and older participants clearly had a preference for the user to the ethnomedicinal plants for curing different health issues. The wider application and adaptation of uses of ethnomedicinal plants and the inclusion of traditional knowledge in decision-making processes at highest level are of great importance. Most of the documented species in the present study have also been reported for multiple uses in various regions of the globe (Table 5). Multiple uses of these plants may incite the appropriate authorities to frame better conservation and management strategies for the plants used for medicinal purposes.

Pharmaceutical medicines cure a range of diseases; however, their higher prices and side effects limit their applications. It is also observed that those living in remote areas who associated with nature used medicinal plants from generations to coming generation although they have minimum side effects, no doubt due to many cases of poisoning associated with herbal medicines increasing in different parts of the world. Therefore, it is also necessary to ensure toxicity assessment on these products for safe use to protect health [38]. In the recent decades, rapid changes in urbanization and its influence on cultural settings has led to the depletion of traditional knowledge in several areas including the Himalayas, due to unorganized way of knowledge transfer to the new 
generations [44]. This state of affairs can lead to the eradication of vast ethnomedicinal understanding of the region if proper documentation is not taken care of. Therefore, to preserve traditional medicinal knowledge, the importance of herbal practitioners and their role in primary healthcare systems should be recognized at the regional as well as national level. This can be achieved by the capacity building of herbal practitioners and education of new generations, which will have a substantial impact on the long-standing sustainability of herbal knowledge [45]. Furthermore, there is an urgent need to document this information, as it is rapidly declining due to the influence of pharmaceutical medicines [46]. Thus, it is important to collect this information and develop a database of medicinal plants for future research and potential development of new herbal medicines.

Table 5. Existing literature of plant species used in different ailments.

\begin{tabular}{|c|c|}
\hline Plant Species & Ailments \\
\hline Justicia adhatoda & $\begin{array}{l}\text { Chronic cold and cough, piles, leprosy, and diabetes [47]; } \\
\text { cough and cold, chronic bronchitis [48] }\end{array}$ \\
\hline & Anti-amoebic and anti-fertility activity [49]; treatment of cancer, \\
\hline Achyranthes aspera & $\begin{array}{l}\text { leprosy, asthma, fistula, piles, arthritis, wound, insect and snake bite, } \\
\text { dandruff, hepatitis [50] }\end{array}$ \\
\hline Allium сера & Edible condiments, vegetable [51] \\
\hline Allium sativum & Cardiovascular disease, diabetes, blood pressure [52] \\
\hline Phyllanthus emblica & Constipation, fever, itching, digestive [53-55] \\
\hline Coriandrum sativum & Antioxidant [56] \\
\hline Calotropis procera & Antitumor, antihelmintic, antioxidant [57] \\
\hline Carissa carandas & Anti-inflammatory and anti-pyretic activity [58] \\
\hline Asparagus curillus & Piles, fever, wound, anti-toxic, weakness, cough [53]; epilepsy [59] \\
\hline Mangifera indica & Cough and cold, dysentery, worm, furniture, leaf religious [53] \\
\hline Ageratum conyzoides & Muscular pain, piles, ring worm, snake bite [60]; control bleeding [61] \\
\hline Anaphalis adnata & Juice applied on fresh cuts and wounds [62] \\
\hline Artemisia vulgaris & Nervous and spasmodic affections, asthma [63] \\
\hline Bauhinia vahlii & Dysentery [64] \\
\hline Cannabis sativa & Diarrhea and body pain [64] \\
\hline Eupatorium adenophorum & Juice applied on fresh cut [64] \\
\hline Berberis asiatica & Conjunctivitis and eye inflammation [65] \\
\hline Brassica campestris & Fever, indigestion, and irritation [66] \\
\hline Oxalis corniculata & Diarrhea, piles, anemia, and eye problems $[62,66]$ \\
\hline Mentha arvensis & Rheumatism, fever, weakness, ulcer, wounds, jaundice, cough, asthma, and cuts [66] \\
\hline Dioscorea bulbifera & Edible [67] \\
\hline Carica papaya & Heart problem, skin problem, piles [53]; bone fracture [67] \\
\hline Terminalia belerica & Fruit for piles, dropsy, diarrhea, leprosy, headache [68]; cold, constipation, piles [60] \\
\hline Terminalia chebula & Digestion, skin problem [53]; cold, cough, fever, stomach ache [69]; diabetes [70] \\
\hline Lagenaria siceraria & Jaundice, diarrhoea, and dysentery $[71,72]$ \\
\hline Melia azedarach & Stomatitis, internal worm, stone in urinary bladder [53]; fever [72] \\
\hline Murraya koenigii & Anemia, vomiting, wound [53]; vomiting, dysentery [72] \\
\hline Ocimum sanctum & bronchitis, asthma, and genitourinary disorders [73]; cold and cough [48] \\
\hline Perilla frutescens & Cough and nausea $[74]$ \\
\hline Cinnamon tamala & $\begin{array}{l}\text { Antigonorrhoeic, hypoglycemic, stimulant, anti-rheumatic, } \\
\text { and antidote for scorpion sting }[75,76]\end{array}$ \\
\hline Abrus precatorius & Antidote, dental caries, baldness, dandruff, erysipelas [77] \\
\hline Butea monosperma & Tuberculosis [78] \\
\hline Syzizium cumini & Dysentery [78] \\
\hline Glycine $\max$ & Cholesterol lowering and anticancer [79] \\
\hline Trigonellafoenum-graecum & Diabetes, stomach complaints [80]; easier delivery [81] \\
\hline Punica granatum & Diarrhea, fever, indigestion [82]; heart problem, eye, and ear disorder, jaundice [53] \\
\hline Woodfordia fruticosa & Leprosy, toothache, leucorrhea, fever, dysentery, bowel disease [83] \\
\hline Ficus subincisa & Boils [84] \\
\hline Datura stramonium & Against rabies, nervousness, nausea, and hysteria [84] \\
\hline Myrica esculenta & Sinusitis [85] \\
\hline
\end{tabular}


Table 5. Cont.

\begin{tabular}{cl}
\hline Plant Species & \multicolumn{1}{c}{ Ailments } \\
\hline Sesamum orientale & Skin for sunburns and ringworm [86] \\
Cynodon dactylon & Antiseptic, snake bite, stop bleeding, wounds, miscarriage [59,87] \\
Hordeum vulgare & Beriberi, cough, influenza, measles, syphilis, nephritis, jaundice, \\
Tinospora cordifolia & dysentery, abortion, common cold, kidney diseases, skin diseases [88] \\
Ziziphus mauritiana & Piles, eye problem, fever, jaundice [53]; jaundice [72] \\
Aegle marmelos & Dried fruits use for anodyne, anticancer, refrigerant, sedative, stomachache [89] \\
Grewia optiva & Stomach-ache, cures cough, good for asthma, tumors [90]; dysentery [80] \\
Rhododendron arboreum & Antibacterial, antifungal, antioxidant [91] \\
Rhus parviflora & Diarrhea and headache [66] \\
Semecarpus anacardium & Antimicrobial [54] \\
Shorea robusta & Anti-atherogenic, anti-inflammatory, antioxidant, antimicrobial, anti-reproductive [55] \\
& Dysentery, antidote [53]; burning sensation, chest pain, small pox [60] \\
Vitex negundo & Headache, stomach problem, diarrhea, rheumatism, bone fracture, body swelling, \\
& swelling of joints, cancer, liver complaints, jaundice, fuelwood branches for making \\
\hline
\end{tabular}

Uttarakhand has great potential for the cultivation of medicinal plants as important sources of sustainable livelihoods. Medicinal and aromatic plants can play an important role in the subsistence livelihood enhancement of rural people. In Uttarakhand State, MAP (Medicinal and Aromatic plants) are an important non-timber forest product and their sustainable trade and commercialization have the potential to generate employment and improve the economy of many rural communities. The region's diverse geo-climatic conditions and rich availability of forest-grown MAP resources mean it has much potential to become a vibrant hub for Northern India's MAP industry. However, current management practices including a disorganized pattern of trade are hampering the conservation of Uttarakhand MAP resources and their potential for sustainable commercialization. The remoteness of many communities in the region is restricting their participation in the industry. There are also limited data on the quantity of MAP being supplied from the region, and so their monetary contribution to India's overall MAP trade is not well defined. To help overcome the challenges facing the MAP industry in Uttarakhand, there is a need to better understand the sector's complex socioecological and socioeconomic conditions and interrelationships. Although there is currently trade and commercialization of MAP in the region, it is not considered to be working within a sustainable business platform. Hence, there is a need to find practical solutions for the sustainable commercialization of MAP in Uttarakhand State. This requires developing strategic marketing prospects for individual businesses and the industry as a whole.

\section{Conclusions}

This study provides broad information about the traditional knowledge of medicinal plants used by rural inhabitants of Garhwal Himalaya, which is under threat of being lost in the near future because of climate change vulnerability in the Himalaya region. Medicinal plants and their traditional formulations have always been a part of the livelihood of rural inhabitants, which have proved to be very useful in dealing with various health issues. Results of this study showed a significant relation between medicinal plant use with a distance of hospital from the household, monthly income of family, and distance of forest from household. Thus, it can be concluded that rural inhabitants of Garhwal Himalaya have sound ethnomedicinal knowledge of curing various health-related issues by the use of local medicinal plants accessible to them from their vicinity.

This study provides baseline information for more scientific studies that may lead to the discovery of new plant-based drugs that will help in the development of effective herbal medicines in the coming decades. In the present situation, more dependency of young people on allopathic medicine systems has led to the degradation of traditional knowledge systems. Therefore, the present circumstances must document the traditional 
knowledge related to medicinal uses of plants and their conservation for future generations. This is important because currently, the younger generation is barely interested in learning and using old age practices. The findings of the study highlight a need for the development of methods or policies which can help in conserving the traditional knowledge of plants used by rural inhabitants in healthcare and thus, in sustaining rural health problems.

Author Contributions: Field study and analyzed data, M.K., S.R., and B.N.; the first draft of the manuscript, M.K., N.A.P., and J.A.B.; read and revised the draft manuscript, N.A.P., J.A.B., A.K., R.W.B., R.K., and M.C.-P. All authors have read and agreed to the published version of the manuscript.

Funding: This research was partially funded by the Project UID/GEO/04035/2019 (GeoBioTec Research Centre) financed by FCT—Fundaçãopara a Ciência e Tecnologia.

Institutional Review Board Statement: Before conducting study in the area, all participants were asked for their free prior informed consent before interview was conducted. All plant specimens reported in the present study were processed, verified and submitted to Garhwal University Herbarium (GUH) and crosschecked. The specimens were from GUH-21001 to GUH-21088 submitted in the GUH for future record.

Informed Consent Statement: Informed consent was obtained from all subjects involved in the study.

Data Availability Statement: Data sets used in this study is available on reasonable request from corresponding or first author.

Acknowledgments: H.N.B. Garhwal University is highly acknowledged for providing this opportunity and the authors are thankful to the inhabitants of the study area who so willingly gave their time, shared their knowledge and cooperation during the field surveys and interviews.

Conflicts of Interest: The authors declare no conflict of interest.

$\begin{array}{ll}\text { Abbreviations } \\ \text { Fic } & \text { informant consensus factor } \\ \text { FL } & \text { fidelity value } \\ \mathrm{CI} & \text { cultural importance index } \\ \mathrm{WHO} & \text { World Health Organization } \\ \mathrm{GUH} & \text { Garhwal University Herbarium } \\ \mathrm{NC} & \text { health problems } \\ \mathrm{N} & \text { total number of informants } \\ \mathrm{N}_{\mathrm{t}} & \text { Number of taxa used } \\ \mathrm{N}_{\mathrm{ur}} & \text { Number of use reports } \\ \mathrm{MAP} & \text { Medicinal and Aromatic plants } \\ \mathrm{NS} & \text { non-significant } \\ \mathrm{GEN} & \text { Gender of respondent } \\ \text { AGE } & \text { Age of respondent } \\ \text { EDU } & \text { Education level of respondent } \\ \text { PROF } & \text { Profession } \\ \mathrm{HEAL} & \text { Healer } \\ \text { DISTFOR } & \text { Distance from forest } \\ \text { DISTHOSP } & \text { Distance from hospital } \\ \text { INCOME } & \text { Monthly income }\end{array}$




\section{Appendix A}

Questionnaire was used to collect information on plant use.

Informant Details

Name:

Sex:

Age:

Village name: $\quad$ Panchayat name:

Block name:

Main occupation:

District name:

Education:

Subsidiary occupation

Ethnobotanical uses of plants:

Source income/Monthly income:

1. Local/vernacular name of plant:

2. Scientific name of plant:

3. Part used of plant:

4. Name of ailment/other purposes in which plant part is used:

5. Mode of preparation:

6. Use (externally/internally):

7. Availability in natural habitat:

8. Cause of declining of ethnobotanical plants if any (overgrazing, encroachments, forest fire, mining activities, climatic change, and others):

9. Who knows best about plant and uses: vaids, shepherds, old people/new generation, and others:

10. Any ethnobotanical plant species under cultivation:

11. Any awareness camps/trainings/exposure visits organized for ethnobotanical plants:

12. Any conservation practices on ethnobotanical plants:

\section{Appendix B. Medicinal Plants Used for Healthcare Practices by Inhabitants}




\begin{tabular}{|c|c|c|c|c|c|c|c|c|c|}
\hline $\begin{array}{l}\text { Scientific Name } \\
\text { and Family }\end{array}$ & $\begin{array}{c}\text { Voucher } \\
\text { Specimen No. }\end{array}$ & $\begin{array}{l}\text { Local } \\
\text { Name }\end{array}$ & $\begin{array}{l}\text { Use } \\
\text { Reports }\end{array}$ & Habit & Part Used & Medicinal Use & Other Uses & $\begin{array}{c}\text { Occurrence } \\
\text { Status } \\
\text { (Gaur, 1999) }\end{array}$ & CI \\
\hline \multicolumn{10}{|c|}{ Acanthaceae } \\
\hline Adhatoda vasica Nees & GUH-21001 & Basingu & 15 & Shrub & & $\begin{array}{l}\text { Flower with honey is used for treating } \\
\text { bronchitis, asthma, cough and cold. }\end{array}$ & $\begin{array}{l}\text { Leaves as } \\
\text { livestock fodder }\end{array}$ & Fairly common & 0.093 \\
\hline \multicolumn{10}{|c|}{ Amaranthaceae } \\
\hline Achyranthes aspera L. & GUH-21002 & Latjeera & 2 & Herb & Whole plant & $\begin{array}{c}\text { Paste of whole plant is used for treating } \\
\text { scorpion and snake bite. }\end{array}$ & None & Fairly common & 0.012 \\
\hline Amaranthus spinosus L. & GUH-21003 & Marsu & 31 & Herb & Leaf, Seed & Helpful in improving appetite, constipation. & $\begin{array}{l}\text { Nutrient } \\
\text { supplement }\end{array}$ & Common & 0.193 \\
\hline \multicolumn{10}{|c|}{ Amaryllidaceae } \\
\hline Allium cepa $\mathrm{L}$. & GUH-21004 & Pyaaj & 17 & Herb & Bulb & $\begin{array}{l}\text { Juice extracted from bulb is used in lice } \\
\text { treatment }\end{array}$ & $\begin{array}{l}\text { Whole plant is } \\
\text { used as nutrient } \\
\text { supplement }\end{array}$ & Common & 0.106 \\
\hline Allium sativum $\mathrm{L}$. & GUH-21005 & Lahsun & 47 & Herb & Bulb & $\begin{array}{l}\text { Bulb heated with mustard oil is helpful in } \\
\text { treating cold. }\end{array}$ & $\begin{array}{l}\text { Whole plant is } \\
\text { used as } \\
\text { flavouring agent } \\
\text { in Indian dishes }\end{array}$ & Common & 0.292 \\
\hline \multicolumn{10}{|c|}{ Anacardiaceae } \\
\hline Mangifera indica L. & GUH-21006 & Aam & 29 & Tree & $\begin{array}{l}\text { Fruit, Leaf, } \\
\text { Twig }\end{array}$ & $\begin{array}{l}\text { Leaves are used for cough treatment and fruit } \\
\text { is helpful in digestion. }\end{array}$ & $\begin{array}{c}\text { Nutrient } \\
\text { supplement, } \\
\text { ritual, fuelwood } \\
\text { Leaves are used }\end{array}$ & Abundant & 0.18 \\
\hline Rhus parviflora Roxb. & GUH-21007 & Tunglu & 20 & Shrub & Leaf & $\begin{array}{l}\text { Leaf paste is applied to wound or cut to stop } \\
\text { bleeding. }\end{array}$ & $\begin{array}{l}\text { for livestock } \\
\text { fodder and twig } \\
\text { for tooth } \\
\text { cleaning }\end{array}$ & Abundant & 0.124 \\
\hline Semecarpus anacardium L. & GUH-21008 & Bhilow & 12 & Tree & Fruit & $\begin{array}{l}\text { Helpful in treating skin allergy, cough, } \\
\text { diarrhea. }\end{array}$ & None & Fairly common & 0.075 \\
\hline \multicolumn{10}{|c|}{ Apiaceae } \\
\hline Coriandrum sativum $\mathrm{L}$. & GUH-21009 & Dhaniya & 8 & Herb & Leaf, Seed & Leaf paste is applied on skin disease. & $\begin{array}{l}\text { Leaf and fruit } \\
\text { are used as } \\
\text { condiment. }\end{array}$ & $\begin{array}{l}\text { Commonly } \\
\text { cultivated }\end{array}$ & 0.050 \\
\hline \multicolumn{10}{|c|}{ Apocyanaceae } \\
\hline $\begin{array}{c}\text { Calotropis procera (Aiton) } \\
\text { W.T. Aiton }\end{array}$ & GUH-21010 & Aak & 5 & Shrub & Root, Latex & Helpful in treating skin problems. & None & Common & 0.031 \\
\hline
\end{tabular}




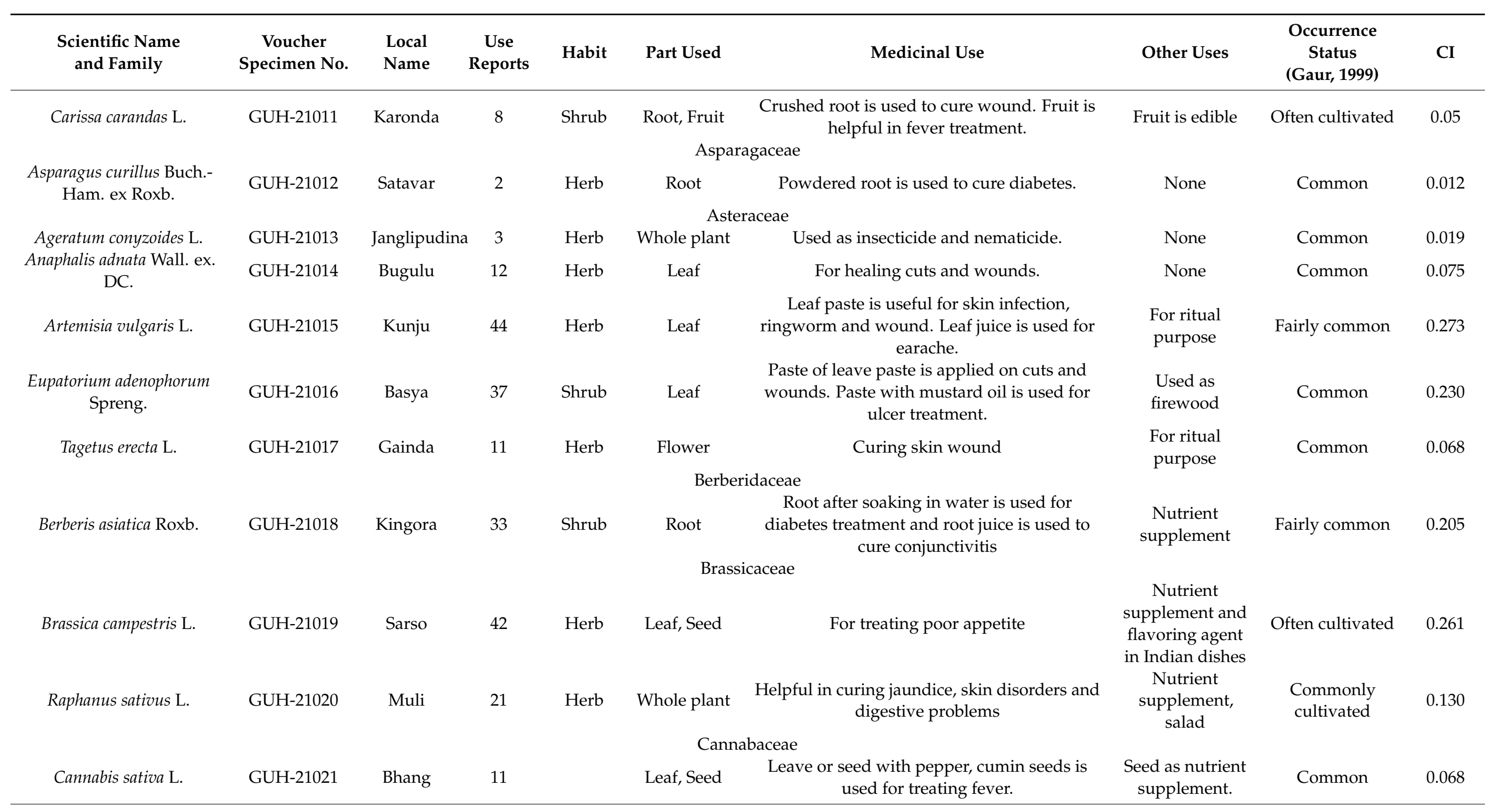




\begin{tabular}{|c|c|c|c|c|c|c|c|c|c|}
\hline $\begin{array}{c}\text { Scientific Name } \\
\text { and Family }\end{array}$ & $\begin{array}{c}\text { Voucher } \\
\text { Specimen No. }\end{array}$ & $\begin{array}{l}\text { Local } \\
\text { Name }\end{array}$ & $\begin{array}{c}\text { Use } \\
\text { Reports }\end{array}$ & Habit & Part Used & Medicinal Use & Other Uses & $\begin{array}{l}\text { Occurrence } \\
\text { Status } \\
\text { (Gaur, 1999) }\end{array}$ & CI \\
\hline \multicolumn{10}{|c|}{ Caricaceae } \\
\hline Carica papaya $\mathrm{L}$. & GUH-21022 & Papita & 33 & Tree & $\begin{array}{l}\text { Seed, Fruit, } \\
\text { Leaf } \\
\quad \text { Cleo }\end{array}$ & $\begin{array}{l}\text { In treating blood pressure, constipation and } \\
\text { dengue. }\end{array}$ & $\begin{array}{c}\text { Nutrient } \\
\text { supplement }\end{array}$ & $\begin{array}{c}\text { Widely } \\
\text { cultivated }\end{array}$ & 0.205 \\
\hline Cleome viscosa $\mathrm{L}$. & GUH-21023 & Jakhiya & 17 & Herb & Seed & Useful in treating high blood pressure. & $\begin{array}{l}\text { Used as } \\
\text { condiment in } \\
\text { dishes }\end{array}$ & Common & 0.106 \\
\hline \multicolumn{10}{|c|}{ Combretaceae } \\
\hline Terminalia belerica Roxb. & GUH-21024 & Bahera & 8 & Tree & Fruit & $\begin{array}{c}\text { Fruit rind is used for treating cough and } \\
\text { dysentery. Used in triphala. }\end{array}$ & $\begin{array}{c}\text { Nutrient } \\
\text { supplement }\end{array}$ & Common & 0.05 \\
\hline Terminalia chebula Retz. & GUH-21025 & Harad & 23 & Tree & Fruit & $\begin{array}{c}\text { Fresh or boiled fruit pulp with honey in } \\
\text { treating of asthma, cough and bronchitis. Also } \\
\text { used in curing piles. }\end{array}$ & $\begin{array}{l}\text { For livestock } \\
\text { fodder }\end{array}$ & Common & 0.143 \\
\hline \multicolumn{10}{|c|}{ Cucurbitaceae } \\
\hline Cucumis sativas $\mathrm{L}$. & GUH-21026 & Kakdi & 16 & Climber & Seed & $\begin{array}{c}\text { Seed paste mixed with water is useful in } \\
\text { urinary problem. }\end{array}$ & $\begin{array}{l}\text { Fruit as nutrient } \\
\text { supplement }\end{array}$ & $\begin{array}{l}\text { Commonly } \\
\text { cultivated }\end{array}$ & 0.099 \\
\hline $\begin{array}{l}\text { Lagenaria siceraria } \\
\text { (Molina) Standl. }\end{array}$ & GUH-21027 & Lauki & 29 & Climber & Fruit & $\begin{array}{c}\text { Helps in curing urinary disorders, indigestion } \\
\text { and stomach acidity }\end{array}$ & $\begin{array}{l}\text { Nutrient } \\
\text { supplement }\end{array}$ & Cultivated & 0.18 \\
\hline $\begin{array}{l}\text { Luffa cylindrica (L.) M. } \\
\text { Roem. }\end{array}$ & GUH-21028 & Tori & 13 & Climber & Fruit & Helps in curing anemia and liver disorders & $\begin{array}{l}\text { Nutrient } \\
\text { supplement }\end{array}$ & Cultivated & 0.081 \\
\hline Momordica charantia $\mathrm{L}$. & GUH-21029 & Karela & 3 & Climber & Fruit & Helpful in curing diabetes & $\begin{array}{l}\text { Nutrient } \\
\text { supplement }\end{array}$ & $\begin{array}{l}\text { Commonly } \\
\text { cultivated }\end{array}$ & 0.019 \\
\hline \multicolumn{10}{|c|}{ Dipterocarpaceae } \\
\hline Shorea robusta Gaertn. & GUH-21030 & Sal & 6 & Tree & $\begin{array}{l}\text { Bark } \\
\text { Disce }\end{array}$ & $\begin{array}{l}\text { Bark paste is used in treating skin diseases. } \\
\text { eaceae }\end{array}$ & None & Common & 0.037 \\
\hline Dioscorea bulbifera L. & GUH-21031 & Genthi & 3 & Climber & Tuber & $\begin{array}{c}\text { Cooked tubers are used in curing ulcers and } \\
\text { piles. }\end{array}$ & $\begin{array}{l}\text { Tuber used as } \\
\text { vegetable }\end{array}$ & Common & 0.019 \\
\hline \multicolumn{10}{|c|}{ Ericaceae } \\
\hline $\begin{array}{l}\text { Rhododendron arboreum } \\
\text { Sm. }\end{array}$ & GUH-21032 & Burans & 5 & Tree & Flower & Flower juice is used for curing blood pressure. & $\begin{array}{l}\text { Leaves used for } \\
\text { livestock fodder }\end{array}$ & Common & 0.031 \\
\hline \multicolumn{10}{|c|}{ Euphorbiaceae } \\
\hline Phyllanthus emblica L. & GUH-21033 & Amla & 33 & Tree & Fruit & Hair wash, skin smoothening. & $\begin{array}{c}\text { Nutrient } \\
\text { supplement }\end{array}$ & Common & 0.205 \\
\hline
\end{tabular}




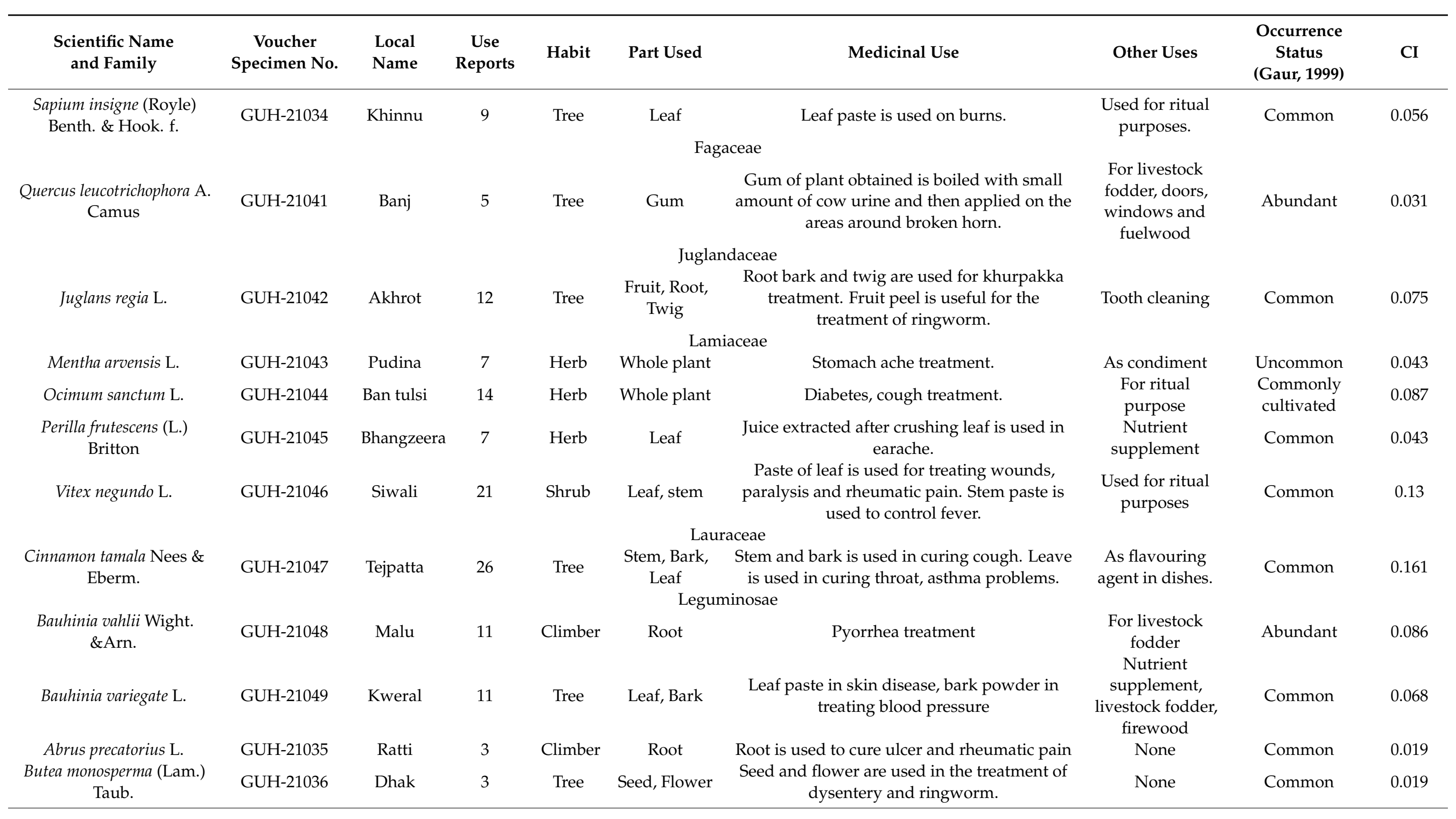




\begin{tabular}{|c|c|c|c|c|c|c|c|c|c|}
\hline $\begin{array}{l}\text { Scientific Name } \\
\text { and Family }\end{array}$ & $\begin{array}{c}\text { Voucher } \\
\text { Specimen No. }\end{array}$ & $\begin{array}{l}\text { Local } \\
\text { Name }\end{array}$ & $\begin{array}{l}\text { Use } \\
\text { Reports }\end{array}$ & Habit & Part Used & Medicinal Use & Other Uses & $\begin{array}{l}\text { Occurrence } \\
\text { Status } \\
\text { (Gaur, 1999) }\end{array}$ & $\mathrm{CI}$ \\
\hline Glycine max (L.) Merr. & GUH-21037 & $\begin{array}{c}\text { Kala } \\
\text { bhatt }\end{array}$ & 11 & Herb & Seed & Seed paste is used for eye sores. & $\begin{array}{c}\text { Nutrient } \\
\text { supplement }\end{array}$ & Cultivated & 0.068 \\
\hline $\begin{array}{l}\text { Macrotyloma uniflorum } \\
\text { (Lam.) Verdc. }\end{array}$ & GUH-21038 & Ghaith & 26 & Herb & Seed & $\begin{array}{c}\text { Seed soaked in water are helpful in treating } \\
\text { kidney stones }\end{array}$ & $\begin{array}{c}\text { Nutrient } \\
\text { supplement }\end{array}$ & $\begin{array}{l}\text { Commonly } \\
\text { cultivated }\end{array}$ & 0.161 \\
\hline Ougeinia oojeiensis Hochr. & GUH-21039 & Sandhan & 2 & Tree & Gum & Gum is used for treating digestive trouble. & $\begin{array}{l}\text { Wood for timber } \\
\text { and firewood } \\
\text { purpose }\end{array}$ & Common & 0.012 \\
\hline $\begin{array}{c}\text { Trigonella foenum-graecum } \\
\text { L. }\end{array}$ & GUH-21040 & Methi & 47 & Herb & Leaf, Seed & Helps in lowering cholesterol & $\begin{array}{l}\text { Used as } \\
\text { flavoring agent } \\
\text { in Indian dishes }\end{array}$ & Often cultivated & 0.292 \\
\hline \multicolumn{10}{|c|}{ Linaceae } \\
\hline $\begin{array}{l}\text { Reinwardtia indica } \\
\text { Dumort. }\end{array}$ & GUH-21050 & Phionly & 6 & Herb & $\begin{array}{r}\text { Whole plant } \\
\text { Lytl }\end{array}$ & $\begin{array}{l}\text { Used for treating cattle diseases and wounds. } \\
\text { aceae }\end{array}$ & $\begin{array}{l}\text { Used as } \\
\text { livestock fodder }\end{array}$ & Common & 0.037 \\
\hline Punica granatum $\mathrm{L}$. & GUH-21051 & Anar & 13 & Tree & Root & $\begin{array}{l}\text { Roots are grinded to powder and then mixed } \\
\text { with half liter of water and fed to animal to } \\
\text { remove internal parasite. }\end{array}$ & $\begin{array}{c}\text { Nutrient } \\
\text { supplement }\end{array}$ & Cultivated & 0.081 \\
\hline Woodfordia fruiticosa $\mathrm{L}$. & GUH-21052 & Dhaula & 2 & Shrub & Flower & Dried flowers are used in dysentery. & $\begin{array}{l}\text { Used for } \\
\text { livestock fodder }\end{array}$ & Common & 0.012 \\
\hline \multicolumn{10}{|c|}{ Malvaceae } \\
\hline Bombax ceiba $\mathrm{L}$. & GUH-21053 & Semal & 5 & Tree & Bark & Curing joint break & $\begin{array}{c}\text { Nutrient } \\
\text { supplement }\end{array}$ & Common & 0.031 \\
\hline $\begin{array}{l}\text { Grewia optiva Drumm. ex } \\
\text { Burret }\end{array}$ & GUH-21086 & Bhimal & 27 & Tree & $\begin{array}{l}\text { Bark, Twig, } \\
\text { Leaf }\end{array}$ & Hair wash & $\begin{array}{l}\text { Rope making, } \\
\text { fuelwood, } \\
\text { fodder }\end{array}$ & Common & 0.037 \\
\hline Melia azedarach $\mathrm{L}$. & GUH-21054 & Dainkan & 7 & Tree & $\begin{array}{l}\text { Me } \\
\text { Leaf, Seed, } \\
\text { Bark, Root } \\
\quad \text { Menisp }\end{array}$ & aceae & $\begin{array}{l}\text { For livestock } \\
\text { fodder. }\end{array}$ & Common & 0.043 \\
\hline $\begin{array}{l}\text { Tinospora cordifolia (Willd.) } \\
\text { Miers ex Hook. f. \& } \\
\text { Thomson }\end{array}$ & GUH-21055 & Gilloi & 31 & Climber & Twig & $\begin{array}{l}\text { Fever, respiratory problems, indigestion } \\
\text { treatment. }\end{array}$ & None & Not uncommon & 0.193 \\
\hline
\end{tabular}




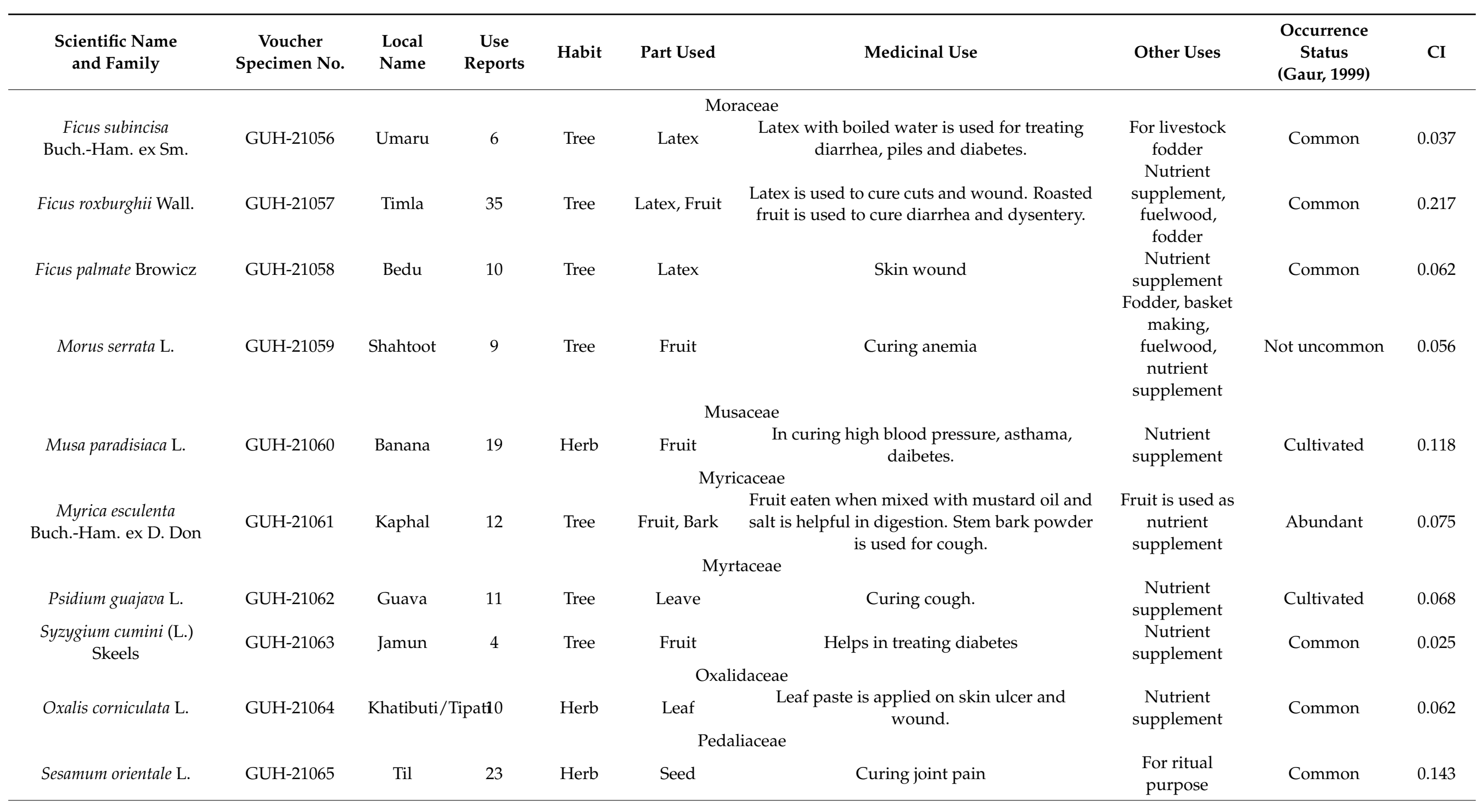




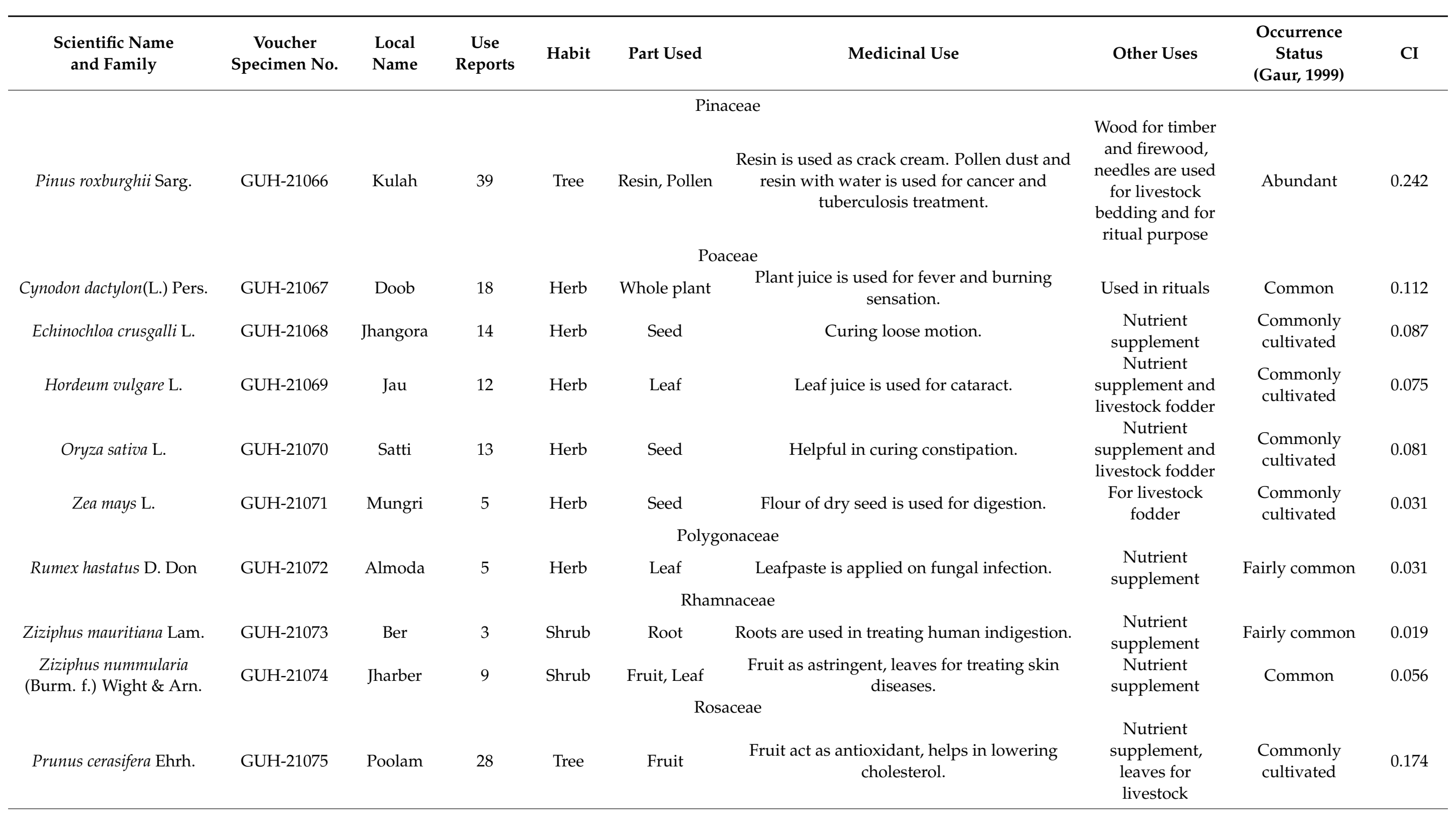




\begin{tabular}{|c|c|c|c|c|c|c|c|c|c|}
\hline $\begin{array}{l}\text { Scientific Name } \\
\text { and Family }\end{array}$ & $\begin{array}{c}\text { Voucher } \\
\text { Specimen No. }\end{array}$ & $\begin{array}{l}\text { Local } \\
\text { Name }\end{array}$ & $\begin{array}{l}\text { Use } \\
\text { Reports }\end{array}$ & Habit & Part Used & Medicinal Use & Other Uses & $\begin{array}{c}\text { Occurrence } \\
\text { Status } \\
\text { (Gaur, 1999) }\end{array}$ & CI \\
\hline $\begin{array}{l}\text { Prunus cerasoides } \\
\text { Buch.-Ham. ex D. Don }\end{array}$ & GUH-21076 & Panya & 39 & Tree & Fruit, bark & $\begin{array}{l}\text { Fruit is astringent and digestive. Juice of bark } \\
\text { is applied externally to treat backaches. }\end{array}$ & $\begin{array}{c}\text { Ritual, } \\
\text { fuelwood, } \\
\text { nutrient } \\
\text { supplement }\end{array}$ & Common & 0.242 \\
\hline Prunus persica (L.) Batsch. & GUH-21077 & Aadu & 11 & Tree & Leaf & Treating khurpakka & $\begin{array}{l}\text { Nutrient } \\
\text { supplement } \\
\text { Nutrient }\end{array}$ & $\begin{array}{l}\text { Commonly } \\
\text { cultivated }\end{array}$ & 0.068 \\
\hline $\begin{array}{l}\text { Pyrus pashia Buch.-Ham. } \\
\text { ex D. Don }\end{array}$ & GUH-21078 & Melu & 17 & Tree & Fruit & $\begin{array}{l}\text { Juice of ripped fruit is used to cure } \\
\text { conjunctivitis. }\end{array}$ & $\begin{array}{l}\text { supplement, } \\
\text { fodder, } \\
\text { fuelwood }\end{array}$ & Fairly common & 0.106 \\
\hline Rosa macrophylla Lindl. & GUH-21079 & Gulaab & 2 & Shrub & Flower & Skin moisturizer & $\begin{array}{l}\text { For ritual } \\
\text { purpose }\end{array}$ & Uncommon & 0.012 \\
\hline Rubus ellipticus Sm. & GUH-21080 & Hisoola & 5 & Shrub & Root & $\begin{array}{c}\text { Root paste is applied on ulcer and skin } \\
\text { infection. }\end{array}$ & $\begin{array}{c}\text { Nutrient } \\
\text { supplement }\end{array}$ & Common & 0.031 \\
\hline \multicolumn{10}{|c|}{ Rutaceae } \\
\hline Citrus aurantifolia Swingle & GUH-21082 & Nimbu & 5 & Tree & Fruit & Diarrhea treatment & $\begin{array}{c}\text { Nutrient } \\
\text { supplement }\end{array}$ & Uncommon & 0.031 \\
\hline $\begin{array}{l}\text { Murraya koenigii (L.) } \\
\text { Spreng. }\end{array}$ & GUH-21083 & Kadipatta & 3 & Shrub & Leave & Respiratory problem & $\begin{array}{l}\text { As flavoring } \\
\text { agent in dishes }\end{array}$ & Common & 0.019 \\
\hline Zanthoxylum armatum DC. & GUH-21084 & Timru & 23 & Shrub & $\begin{array}{l}\text { Bark, Fruit, } \\
\text { Twig }\end{array}$ & Toothache treatment & Tooth cleaning & Common & 0.143 \\
\hline \multicolumn{10}{|c|}{ Solanaceae } \\
\hline Datura stramonium $\mathrm{L}$. & GUH-21085 & Dhatura & 15 & Herb & Leaf, Flower & $\begin{array}{l}\text { Leave and flower is used to cure bronchitis, } \\
\text { asthma and cough. }\end{array}$ & $\begin{array}{l}\text { Fruit is used for } \\
\text { ritual purpose }\end{array}$ & Common & 0.168 \\
\hline Urtica dioica $\mathrm{L}$. & GUH-21087 & Kandali & 6 & Herb & Urticace & Stomach-ache & $\begin{array}{l}\text { Rope making, } \\
\text { nutrient } \\
\text { supplement }\end{array}$ & Common & 0.106 \\
\hline \multicolumn{10}{|c|}{ Zingiberaceae } \\
\hline $\begin{array}{l}\text { Cautleyaspicata }(\mathrm{Sm} .) \\
\text { Baker }\end{array}$ & GUH-21088 & Jadhaldu & 17 & Herb & Rhizome & $\begin{array}{c}\text { Rhizome paste useful in treatment of skin } \\
\text { burns. }\end{array}$ & None & Common & 0.093 \\
\hline
\end{tabular}




\section{References}

1. Yadav, B.K.V. Problems and Prospects of Medicinal and Aromatic Plants' Cultivation and Marketing (A Case Study from Sarlahi District). Master's Thesis, Tribhuvan University, Institute of Forestry, Pokhara, Nepal, 2008.

2. ICIMOD Brochure. Medicinal and Aromatic Plants Programme in Asia (MAPPA); ICIMOD Brochure: Kathmandu, Nepal, 2006; Available online: www.icimod.org (accessed on 11 May 2017).

3. Lange, D.; Schippmann, U. Trade Survey of Medicinal Plants in Germany: A Contribution to International Plant Species Conservation; Bundesamt für Naturschutz: Bonn, Germany, 1997.

4. Cunningham, A.B. An Investigation of the Herbal Medicine Trade in Natal/Kwa Zulu; Investigational Report Number 29; Institute of Natural Resources, University of Natal: Pietermaritzburg, South Africa, 1988.

5. Awoyemi, O.K.; Ewa, E.E.; Abdulkarim, I.A.; Aduloju, A.R. Ethnobotanical assessment of herbal plants in south western Nigeria. Acad. Res. Int. 2012, 2, 50-57.

6. Tarafdar, R.G.; Nath, S.; Das Talukdar, A.; Choudhury, M.D. Antidiabetic plants used among the ethnic communities of Unakoti district of Tripura, India. J. Ethnopharmacol. 2015, 160, 219-226. [CrossRef]

7. Uniyal, B. Utilization of Medicinal plants by the rural women of Kullu Himachal. Ind. J. Trad. Knowl. 2003, 2, 366-370.

8. Chakraborty, R.; Roy, S.; Mandal, V. Assessment of traditional knowledge of the antidiabetic plants of Darjeeling and Sikkim Himalayas in the context of recent phytochemical and pharmacological advances. J. Integr. Med. 2016, 14, 336-358. [CrossRef]

9. Schippmann, U.; Leaman, D.J.; Cunningham, A.B. Impact of cultivation and gathering of medicinal plants on biodiversity: Global trends and issues. In Biodiversity and the Ecosystem Approach in Agriculture, Forestry and Fisheries; Food and Agriculture Organization (FAO): Rome, Italy, 2002; Available online: http:/ / www.fao.org/3/contents/11fc3667-52a7-5192-8fbb-358daaeaf5 58/AA010E00.pdf (accessed on 11 May 2017).

10. Semwal, D.K.; Chauhan, A.; Kumar, A.; Aswal, S.; Semwal, R.B.; Kumar, A. Status of Indian medicinal plants in the International Union for Conservation of Nature and the future of Ayurvedic drugs: Shouldn't think about Ayurvedic fundamentals? J. Integr. Med. 2019, 17, 238-243. [CrossRef]

11. Ellen, R.F. Classification. In The Routledge Encyclopedia of Social and Cultural Anthropology; Barnard, A., Spencer, J., Eds.; Routledge: London, UK; New York, NY, USA, 2009; pp. 129-133.

12. Maffi, L. Linguistic, cultural, and biological diversity. Annu. Rev. Anthr. 2005, 34, 599-617. [CrossRef]

13. Leonti, M.; Casu, L. Traditional medicines and globalization: Current and future perspectives in ethnopharmacology. Front. Pharmacol. 2013, 4, 92. [CrossRef]

14. Pieroni, A.; Quave, C. Traditional pharmacopoeias and medicines among Albanians and Italians in southern Italy: A compar-ison. J. Ethnopharmacol. 2005, 101, 258-270. [CrossRef]

15. Bandiera, O.; Rasul, I. Social Networks and Technology Adoption in Northern Mozambique. Econ. J. 2006, 116, 869-902. [CrossRef]

16. Chandra, K.; Nautiyal, B.; Nautiyal, M.C. Ethno-botanical Resources as Supplementary Foods and Less Known Wild Edible Fruits in District Rudraprayag, Uttarakhand, India. J. Hum. Ecol. 2013, 42, 259-271. [CrossRef]

17. Purohit, A.N. Overview of State Policies, Plans and Interventions to Promote the Medicinal Plant Sector in Uttaranchal, Searching Synergy; KIT Bulletin 359; Royal Tropical Institute: Amsterdam, The Netherlands, 2004.

18. Kala, C.P.; Farooquee, N.A.; Dhar, U. Prioritization of medicinal plants on the basis of available knowledge, existing practices and use value status in Uttaranchal, India. Biodivers. Conserv. 2004, 13, 453-469. [CrossRef]

19. Malik, Z.A.; Bhat, J.A.; Ballabha, R.; Bussmann, R.W.; Bhatt, A.B. Ethnomedicinal plants traditionally used in health care practices by inhabitants of Western Himalaya. J. Ethnopharmacol. 2015, 172, 133-144. [CrossRef]

20. Cameron, M.M. Modern desires, knowledge control, and physician resistance: Regulating Ayurvedic medicine in Nepal. Asian Med. 2008, 4, 86-112. [CrossRef]

21. Harsha, V.H.; Hebbar, S.S.; Hegde, G.R.; Shripathi, V. Ethnomedical knowledge of plants used by Kunabi Tribe of Karnataka in India. Fitoterapia 2002, 73, 281-287. [CrossRef]

22. Kunwar, R.M.; Bussmann, R.W. Ethnobotany in the Nepal Himalaya. J. Ethnobiol. Ethnomed. 2008, 4, 24. [CrossRef]

23. Singh, J.; Singh, A.; Pravesh, K.R. Production and trade potential of some important medicinal plants: An overview. In Proceedings of the 1st National Interactive Meet on Medicinal and Aromatic Plants; CIMAP: Lucknow, India, 2003.

24. Thakur, K.S.; Kumar, M.; Bawa, R.; Mohammed, O.B. Ethnobotanical Study of Herbaceous Flora along an Altitudinal Gradient in Bharmour Forest Division, District Chamba of Himachal Pradesh, India. Evid. Based Complement. Altern. Med. 2014, $2014,1-7$. [CrossRef]

25. Sharma, C.M.; Gairola, S.; Ghildiyal, S.K.; Suyal, S. Forest Resource Use Patterns in Relation to Socioeconomic Status. Mt. Res. Dev. 2009, 29, 308-319. [CrossRef]

26. Sharma, C.M.; Baduni, N.P.; Nautiyal, D.P. Socio-economic strategies for Environmental conservation in rural Garhwal Himalaya. Ecol. Environ. Conserv. 1999, 5, 227-231.

27. Gairola, S.; Sharma, C.M.; Ghildiyal, S.K.; Suyal, S.; Rana, C.S.; Butola, D.S. Biodiversity Conservation and Sustainable Rural Development in the Garhwal Himalaya. Report Opin. 2009, 1, 1-7. 
28. Mittal, S.; Tripathi, G.; Sethi, D. Development Strategy for the Hill Districts of Uttarakhand; Working Paper No. 217; Indian Council for Research on International Economic Relations: Delhi, India, 2008.

29. Census of India. 2011. Available online: http:/ / www.censusindia.gov.in (accessed on 22 January 2017).

30. Davis, A.; Wagner, J.R. Who knows? On the importance of identifying "experts" when researching local ecological knowledge. Hum. Ecol. 2003, 31, 463-489. [CrossRef]

31. Gaur, R.D. Flora of the District Garhwal Northwest Himalayas: With Ethnobotanical Notes; Transmedia: Srinagar, India, 1999.

32. Nayar, E.R.; Pandey, A.; Venkateshwaran, K.; Gupta, R.; Dhillon, B.S. Crop Plants of India: A Check-List of Scientific Names; National Bureau of Plant Genetic Resources: New Delhi, India, 2003.

33. Trotter, R.; Logan, M. Informant consensus: A new approach for identifying potentially effective medicinal plants. In Plants in Indigenous Medicine and Diet: Biobehavioural Approaches; Etkin, N.L., Ed.; Redgrave Publishers: Bedfort Hills, NY, USA, 1986; pp. 91-112.

34. Ragupathy, S.; Steven, N.G.; Maruthakkutti, M.; Balasubramaniam, V.; Ul-Huda, M.M. Consensus of the 'Malasars' traditional aboriginal knowledge of medicinal plants in the Velliangiri holy hills, India. J. Ethnobiol. Ethnomed. 2008, 4, 8. [CrossRef]

35. Friedman, J.; Yaniv, Z.; Dafni, A.; Palewitch, D. A preliminary classification of the healing potential of medicinal plants, based on a rational analysis of an ethnopharmacological field survey among Bedouins in the Negev Desert, Israel. J. Ethnopharmacol. 1986, 16, 275-287. [CrossRef]

36. Kunwar, R.M.; Shrestha, K.P.; Bussmann, R.W. Traditional herbal medicine in Far-west Nepal: A pharmacological appraisal. J. Ethnobiol. Ethnomed. 2010, 6, 35. [CrossRef]

37. Kala, C.P. Current status of medicinal plants used by traditional Vaidhyas in Uttaranchal State of India. Ethnobot. Res. Appl. 2005, 3, 267-278. [CrossRef]

38. Zhou, J.; Ouedraogo, M.; Qu, F.; Duez, P. Potential Genotoxicity of Traditional Chinese Medicinal Plants and Phytochemicals: An Overview. Phytother. Res. 2013, 27, 1745-1755. [CrossRef]

39. Malla, B.; Gauchan, D.P.; Chhetri, R.B. An ethnobotanical study of medicinal plants used by ethnic people in Parbat district of western Nepal. J. Ethnopharmacol. 2015, 165, 103-117. [CrossRef]

40. Bhat, P.; Hedge, G.R.; Hedge, G.; Mulgund, G.S. Ethnomedicinal plants to cure skin diseases-An account of traditional knowledge in the coastal parts of Central Western Ghats, Karnataka, India. J. Ethnopharmacol. 2014, 1, 493-502. [CrossRef]

41. Joshi, R.K. Voatile oil composition of Artemisia japonicaThunb. From Western Himalaya of Uttarakhand. J. Pharmacog. Phytochem. 2015, 3, 96-97.

42. Sharma, J.; Gairola, S.; Sharma, Y.P.; Gaur, R. Ethnomedicinal plants used to treat skin diseases by Tharu community of district Udham Singh Nagar, Uttarakhand, India. J. Ethnopharmacol. 2014, 158, 140-206. [CrossRef]

43. Kumar, M.; Sheikh, M.A.; Mohammed, O.B. Ethnomedicinal and ecological status of plants in Garhwal Himalaya, India. J. Ethnobiol. Ethnomed. 2011, 7, 32. [CrossRef]

44. Bhattarai, S.; Chaudhary, R.P.; Taylor, R.S.L. Ethnomedicinal plants used by the people of Manang district, central Nepal. J. Ethnobiol. Ethnomed. 2006, 2, 41. [CrossRef]

45. Rokaya, M.B.; Uprety, Y.; Poudel, R.C.; Timsina, B.; Münzbergová, Z.; Asselin, H.; Tiwari, A.; Shrestha, S.S.; Sigdel, S.R. Traditional uses of medicinal plants in gastrointestinal disorders in Nepal. J. Ethnopharmacol. 2014, 158, 221-229. [CrossRef] [PubMed]

46. Singh, A.; Nautiyal, M.C.; Kunwar, R.M.; Bussmann, R.W. Ethnomedicinal plants used by local inhabitants of Jakholi block, Rudraprayag district, western Himalaya, India. J. Ethnobiol. Ethnomed. 2017, 13, 1-29. [CrossRef] [PubMed]

47. Mondal, T.; Samanta, S. An ethnobotanical survey on medicinal plants of Ghatal block, West Midnapur District, West Bengal, India. Int. J. Curr. Res. Biosci. Plants Biol. 2014, 1, 35-37.

48. Bose, D.; Ghosh, R.; Das, J.; Mahapatra, S.; Datta, T.; Das Mahapatra, S.; Biswas, H. Medicinal plants used by tribals in Jalpaiguri district, West Bengal, India. J. Med. Plants Stud. 2015, 3, 15-21.

49. Varuna, K.M.; Khanu, M.U.; Sharma, P.K. Review on Achyranthes aspera. J. Pharm. Res. 2010, 3, 714-717.

50. Dey, A. Achyranthes aspera-Phytochemical and Pharmacological aspects. Int. J. Pharm. Sci. Rev. Res. 2011, 9, 72-82.

51. Geng, Y.; Zhang, Y.; Ranjitkar, S.; Huai, H.; Wang, Y. Traditional knowledge and its transmission of wild edibles used by the Naxi in Baidi Village, northwest Yunnan province. J. Ethnobiol. Ethnomed. 2016, 12, 1-21. [CrossRef] [PubMed]

52. Gebreyohannes, G.; Gebreyohannes, M. Medicinal value of garlic: A review. Int. J. Med. Sci. 2013, 5, 401-408.

53. Singh, U.; Bharti, A.K. Ethnobotanical study of plants of Raigarharea, Chhattisgarh, India. Int. Res. J. Biol. Sci. $2015,4,36-43$.

54. Kumar, G.; Badoni, P.P. Antimicrobial activity of Rhusparviflora Roxb: Leaves extract mediated synthesized Zno nanoparticles. Int. J. Chemtech. Res. 2017, 10, 377-381.

55. Jain, P.; Sharma, H.P. A potential ethnomedicinal plant: Semicarpusanarcardium Linn: A review. Int. J. Resphar. Chem. 2013, 3, 564-572.

56. Rajeshwari, U.; Andallu., B. Medicinal benefits of coriander(Coriandrum sativum L). Spatula DD Peer Rev. J. Complement. Med. Drug Discov. 2011, 1, 51-58. [CrossRef]

57. Sharma, A.K.; Kharb, R.; Kaur, R. Pharmacognostical aspects of Calotropis procera (Ait.). R. Br. Int. J. Pharm. Bio. Sci. 2011, 2, 480-488.

58. Arif, M.; Kamal, M.; Jawaid, T.; Khalid, M.; Saini, K.S.; Kumar, A.; Ahmad, M. Carissa carandus Linn. (Karonda): An exotic minor plant fruit with immense value in nutraceutical and pharmaceutical industries. Asian J. Biomed. Pharm. Stud. 2015, 6, 14-19. 
59. Phondani, P.C.; Maikhuri, R.K.; Rawat, L.S.; Farooquee, N.A.; Kala, C.P.; Vishvakarma, S.C.R.; Rao, K.S.; Saxena, K.G. Ethnobotanical uses of plants among the Bhotiya tribal communities of Niti valley in Central Himalaya, India. Ethnobot. Res. Appl. 2010, 8, 233-244. [CrossRef]

60. Singh, A.; Dubey, N.K. An ethnobotanical study of medicinal plants in Sonebhadra district of Uttar, Pradesh, India with reference to their infection by foliar fungi. J. Med. Plants Res. 2012, 6, 2727-2746.

61. Rai, M.B. Medicinal Plants of Tehrathum District, Eastern Nepal. Our Nat. 2003, 1, 42-48. [CrossRef]

62. Parajuli, R.R. Indigenous Knowledge on Medicinal Plants: Maipokhari, Maimajhuwa and Mabu VDCs of Ilam District, Eastern Nepal. J. Dept. Plant Res. Nepal. 2013, 35, 50-58.

63. Hussain, S.; Hore, D.K. Collection and conservation of major medicinal plants of Darjeeling and Sikkim Himalayas. Ind. J. Trad. Knowl. 2007, 6, 352-357.

64. Lepcha, S.R.; Das, A.P. Ethno-medicobotanical exploration along the international borders to Tibet Autonomous Region of China and the kingdom of Bhutan with special reference to the Pangolakha Wildlife Sanctuary. In Recent Studies in Biodiversity and Traditional Knowledge in India; Gour Mahavidyalaya: West Bengal, India, 2011; pp. 257-270.

65. WWF-Nepal. Gift of the Himalayas: Non Timber Forest Products of the Sacred Himalayan Landscape-Nepal; WWF Nepal: Kathmandu, Nepal, 2007.

66. Parajuli, R.R. Ethnomedicinal Use of Plants in Rai community of Maimajuwa and Puwamajuwa VDCs of Ilam District, Eastern Nepal. Bull. Dept. Plant Res. 2012, 34, 65-73.

67. Malla, S.; Shukla, G.; Chakravarty, S. Utilization and conservation of wild plants by the tribal communities of Tripura. Ind. For. 2012, 138, 1002-1007.

68. Mathur, A.; Joshi, H. Ethnobotanical studies of the terai region of Kumaun, Uttarakhand, India. Ethnol. Res. Appl. 2013, 11, 175-203.

69. Ignacimuthu, S.; Ayyanar, M.; Sankarasivaraman, K. Ethnobotanical investigations among tribes in Madurai District of Tamil Nadu (India). J. Ethnobiol. Ethnomed. 2006, 2, 25. [CrossRef]

70. Shrivastava, S.; Kanungo, V.K. Ethnobotanical survey of Surguja district with special reference to plants used by Uraon tribe in treatment of diabetes. Int. J. Herb. Med. 2013, 1, 127-130.

71. Singh, A.G.; Kumar, A.; Tewari, D.D. An ethnobotanical survey of medicinal plants used in Terai forest of western Nepal. J. Ethnobiol. Ethnomed. 2012, 8, 19. [CrossRef]

72. Padal, S.B.; Chandrasekhar, P.; Satyavathi, K. Ethnomedicinal investigation of medicinal plants used by the tribes of Peda-bayalu Mandalam, Visakhapatnam District, Andhra Pradesh, India. Int. J. Comput. Eng. Res. 2013, 3, 8-13.

73. Ghosh, S.K.; Guria, N.; Sarkar, A.; Ghosh, A. Traditional herbal remedies for various ailments within the rural communities in the district of Bankura and Purulia, West Bengal, India. Int. J. Pharm. Pharm. Sci. 2013, 5, 195-198.

74. Badola, H.K.; Pradhan, B.K. Plants used in healthcare practices by Limboo tribe in South-West of Khangchendzonga Biosphere Reserve, Sikkim. Ind. J. Trad. Knowl. 2013, 12, 355-369.

75. Shah, M.; Panchal, M. Ethnoparmacological properties of Cinnamomum tamala-A review. Int. J. Pharmsci. Rev. Res. 2010, 5, 141-144.

76. Moktan, S.; Das, A.P. Ethnomedicinal approach for diarrhoeal treatment in Darjiling district (WB), India. Ethnobot 2013, 25, 160163.

77. Chaudhari, K.S.; Sharma, R.; Pawar, P.S.; Kashikar, V.A. Pharmacological activities of Abrusprecatorius L.: A review. JAHM 2012, 2, 336-340.

78. Siwakoti, M.; Siwakoti, S. Ethnomedicinal uses of plants among the Satar tribe of Nepal. JETB 2010, 24, 323-333.

79. Sharma, A.; Baluja, Z. Therapeutic effects of Glycine max (Soybena): A summary. Int. J. Pharm. Biosci. 2015, 2, $22-27$.

80. Jennings, H.M.; Merrell, J.; Thompson, J.L.; Heinrich, M. Food or medicine? The food-medicine interface in households in Sylhet. J. Ethnopharmcol. 2015, 167, 97-104. [CrossRef]

81. Verma, R.K. An ethnobotanical study of plants used for the treatment of livestock diseases in Tikamgarh District of Bundel-khand, Central India. Asian Pac. J. Trop. Biomed. 2014, 4, 460-467. [CrossRef]

82. Yonzone, R.; Bhujel, R.B.; Rai, S. Genetic resources, current ecological status and altitude wise distribution of medicinal plants diversity of Darjeeling Himalaya of West Bengal, India. Asian Pac. J. Trop. Med. 2012, 2, S439-S445. [CrossRef]

83. Kumar, D.; Sharma, M.; Sarout, A.; Saroha, K.; Verma, S. Woodfordiafructicosa Karz. A review on its botany chemistry and biological activities. J. Pharmacogn. Phytochem. 2016, 5, 293-298.

84. Bantawa, P.; Rai, R. Studies on ethnomedicinal plants used by traditional practitioners, Jhankri, Bijuwa and Phedangma in Darjeeling Himalaya. Nat. Prod. Rad. 2009, 8, 537-541.

85. Gautam, T.P. Indigenous uses of some medicinal plants in Panchthar district, Nepal. Nepal. J. Biosci. 2013, 1, 125-130. [CrossRef]

86. Rai, S. Medicinal Plants used by Meche People of Jhapa District, Eastern Nepal. Our Nat. 2004, 2, 27-32. [CrossRef]

87. Das, H.B.; Majumdar, K.; Datta, B.K.; Ray, D. Ethnobotanical uses of some plants by Tripuri and Reang tribes of Tripura. Nat. Prod. Rad. 2009, 8, 172-180.

88. Marwat, S.K.; Hashimi, M.; Khan, K.V.; Khan, M.A.; Shoaib, M.; Rehman, F. Barley (Hordeumvulgare L.) a prophetic food men-tioned in ahadith and its ethnobotanical importance. Am. Eurasian J. Agric. Environ. Sci. 2012, 12, 835-841.

89. Palejkar, C.J.; Palejkar, J.H.; Patel, A.J.; Patel, M.A. A plant review of Ziziphus mauritiana. Int. J. Univerpharm. Lifesci. 2012, 2, 202-211. 
90. Anand, S.P.; Deborah, S. Enumeration of wild edible fruits from Bodahills and Kolli hills. Int. J. Appl. Biol. Pharm. Technol. 2016, 7, 96-102.

91. Arora, S. Antimicrobial, antifungal, antioxidant and phytochemical study of the leaves extract of Grewia optiva. J. Pharm. Res. 2011, 4, 3130-3132.

92. Ghosh, A. Ethnomedicinal plants used in West Rahrr region of West Bengal. Nat. Prod. Rad. 2008, 75, 461-465. 